UNIVERSIDADE DE SÃO PAULO

FACULDADE DE ECONOMIA, ADMINISTRAÇÃO E CONTABILIDADE DEPARTAMENTO DE ADMINISTRAÇÃO PROGRAMA DE PÓS-GRADUAÇÃo EM EMPREENDEDORISMO

ESCRITÓRIO DE GERENCIAMENTO DE PROJETOS: UM ESTUDO SOBRE OS BENEFÍCIOS E FATORES LIMITANTES DE SUA IMPLANTAÇÃO

Irina Bullara Martins Lachowski

Orientador: Prof. Dr. Antonio Cesar Amaru Maximiano

SÃO PAULO 
Prof. Dr. Marco Antonio Zago

Reitor da Universidade de São Paulo

Prof. Dr. Adalberto Américo Fischmann

Diretor da Faculdade de Economia, Administração e Contabilidade

Prof. Dr. Roberto Sbragia

Chefe do Departamento de Administração

Prof. Dr. Martinho Isnard Ribeiro de Almeida

Coordenador do Programa de Mestrado Profissional em Empreendedorismo 


\title{
ESCRITÓRIO DE GERENCIAMENTO DE PROJETOS: UM ESTUDO SOBRE OS BENEFÍCIOS E FATORES LIMITANTES DE SUA IMPLANTAÇÃO
}

\author{
Dissertação apresentada ao Programa de Pós- \\ Graduação em Mestrado Profissional \\ Empreendedorismo, do Departamento de \\ Administração, da Faculdade de Economia, \\ Administração e Contabilidade da \\ Universidade de São Paulo, como requisito \\ parcial para a obtenção do título de Mestre em \\ Ciências.
}

Orientador: Prof. Dr. Antonio Cesar Amaru Maximiano

\begin{abstract}
Versão Corrigida
(versão original disponível na Biblioteca da Faculdade de Economia, Administração e Contabilidade)
\end{abstract}

\section{SÃO PAULO}


FICHA CATALOGRÁFICA

Elaborada pela Seção de Processamento Técnico do SBD/FEA/USP

Lachowski, Irina Bullara Martins

Escritório de gerenciamento de projetos: um estudo sobre os benefícios e fatores limitantes de sua implantação / Irina Bullara Martins Lachowski. -- São Paulo, 2016.

$92 \mathrm{p}$.

Dissertação (Mestrado) - Universidade de São Paulo, 2016.

Orientador: Antonio Cesar Amaru Maximiano.

1. Administração de projetos 2. Gerenciamento de projetos 3. Escritórios 4. Pesquisa-ação I. Universidade de São Paulo. Faculdade de Economia, Administração e Contabilidade. II. Título.

CDD -658.504 
Dedico àqueles que me fazem uma pessoa melhor: meu esposo Felipe, José Carlos e Lucas e, ao meu grande exemplo, Denise. 



\section{AGRADECIMENTOS}

Fazer um Mestrado Profissional não foi tarefa fácil, a conciliação entre teoria e prática, tão importantes para a confecção desta dissertação, exigiu esforço e resiliência não só de minha parte, também de muitos daqueles que me acompanharam durante minhas escolhas profissionais e minha jornada acadêmica.

Agradeço à "Alta Administração", tão citada ao longo da minha dissertação, que confiou em meu trabalho, incentivou minhas ideias e, por dois anos de mestrado, não deixou de me proporcionar desafios cada vez maiores. Obrigada pelas oportunidades, pelo reconhecimento do meu trabalho e pela confiança, essencial, em mim.

Agradeço ao Antonio Amaru, orientador e professor, que me recebeu carinhosamente e não desistiu de mim ao longo desta jornada. Além de um exímio conhecedor do tema, sempre esteve disponível, com sensibilidade e humildade para orientar e indicar o melhor caminho. Agradeço ao professor Martinho pela paciência com a turma novata e pela proatividade no lançamento do Mestrado Profissional em Empreendedorismo, que nos propiciou uma ampliação de horizontes em termos práticos e acadêmicos.

Agradeço ao professor Marcelo, quem primeiro me incentivou no caminho acadêmico e a pessoa que, em minha qualificação, abriu novas possibilidades de desenvolvimento do tema. Agradeço à Fabi que não me deixou desistir e me ajudou tantas vezes, com sua serenidade e olhar carinhoso, que lhe são peculiares.

Agradeço aos colegas do Mestrado pela parceira, risos e desesperos contíguos, em especial Milton, Débora, Renata e Andrea. Um espaço em meu coração está reservado para vocês. Agradeço aos meus sogros, à Karina e ao Heleno que me apoiam e caminham ao meu lado em todas as minhas decisões profissionais. Agradeço à Karina, em especial, por compartilhar comigo os sentimentos que a escrita de uma dissertação pode causar.

Agradeço à Mayra, minha irmã, que esteve comigo até a última revisão, demonstrando o orgulho de fazer parte desta conquista.

Agradeço aos meus pais, responsáveis pela minha educação e pelas minhas escolhas. Elas são apenas um simples reflexo do caráter de vocês. Obrigada pelo apoio, pelo exemplo e pelo amor incondicional.

Agradeço ao meu irmão, Lucas, por ser meu maior exemplo acadêmico, meu esteio e a pessoa mais sensata, que sempre traz paz ao meu caminho.

Agradeço ao meu marido, Felipe, pelo apoio incondicional, pelos finais de semanas em casa, pelo orgulho constante em seu olhar. Agradeço pelo seu amor e parceira, sem eles nada seria possível. 

"É só dos sentidos que procede toda a autenticidade, toda a boa consciência, toda a evidência da verdade." Friedrich Nietzsche 



\section{RESUMO}

A presente dissertação tem por objetivo avaliar a implantação de um Escritório de Gerenciamento de Projetos (EGP), colocando-o como uma ferramenta eficaz para minimizar os problemas de gerenciamento de projetos, garantindo, assim, a execução da estratégia de longo prazo, que culmina na evolução e no crescimento das empresas. Por meio de uma experiência prática, objeto do Mestrado Profissional, essa dissertação descreve a implantação de um EGP que objetivou manter a coerência entre estratégia e os projetos em andamento em uma empresa de educação. A metodologia utilizada foi uma pesquisa exploratória descritiva de abordagem qualitativa, desenvolvida a partir de uma pesquisa-ação. A pesquisa-ação permitiu a verificação, após dois anos desta implantação, dos principais benefícios e fatores limitantes do EGP. Os principais resultados foram (i) a descrição de um passo a passo para a implantação de um Escritório de Gerenciamento de Projetos, em consonância com os preceitos teóricos e com a prática vivenciada, dando ênfase aos seus fatores de sucesso e (ii) a verificação dos principais benefícios e fatores limitantes para a organização, que podem ser apresentados nas dimensões estratégica, organizacional e operacional. A conclusão é que o EGP foi benéfico para a empresa, uma vez que alinhou a estratégia aos projetos em execução, garantiu a gestão e o acompanhamento de prioridades tanto para a Alta Administração quanto para os demais níveis da empresa, favoreceu a implantação de uma cultura projetizada e auxiliou na evolução do modelo de gestão da empresa.

Palavras-chave: Administração de projetos, gerenciamento de projetos, escritórios, pesquisa-ação. 



\begin{abstract}
This dissertation aims to evaluate the implementation of a Project Management Office (PMO), placing it as an effective tool to minimize project management problems, thus ensuring the implementation of the long-term strategy, which culminates the companies' growth. Through practical experience, Professional Master object, this thesis describes the implementation of a PMO aimed to maintain consistency between strategy and ongoing projects in an education company. The methodology used was a descriptive exploratory study of qualitative approach, and its method an action research. The action research allowed to check, after two years of this implementation, the main benefits and the limiting factors of PMO. The main results were: (i) the description of a step by step to the implementation of a Project Management Office, in line with the theoretical principles and the experienced practice with emphasis on their success factors and (ii) the verification of the main benefits and limiting factors for the organization, which can be listed in strategic, organizational and operational dimensions. The conclusion is that the PMO was beneficial to the company, since it has aligned strategy to projects running, secured the management and monitoring of priorities for both the senior management and to the other levels of the company, favored the establishment of a projected culture and helped in the evolution of the company's management model.
\end{abstract}

Keywords: Project management, project management office, office, action research. 



\section{SUMÁRIO}

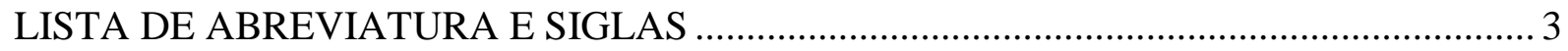

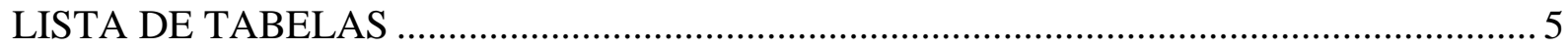

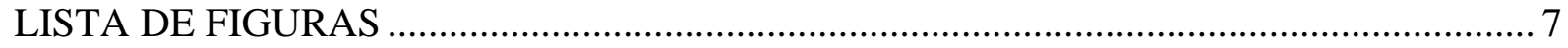

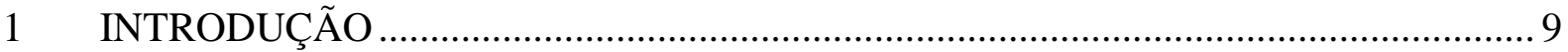

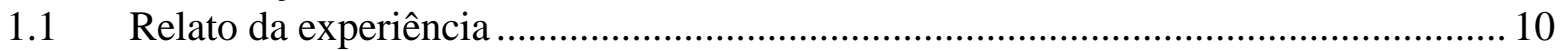

1.1.1 Unidade de Análise ...................................................................................... 12

1.1.2 Implantação de um Escritório de Gerenciamento de Projetos .............................. 13

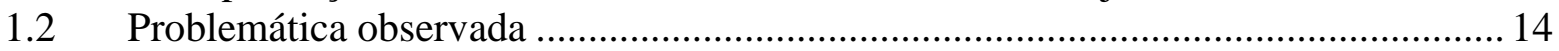

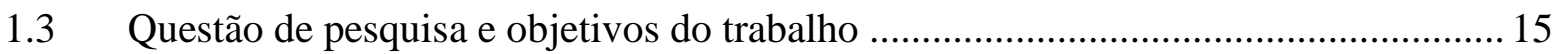

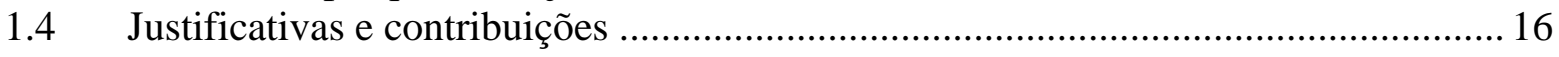

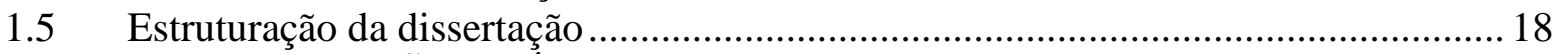

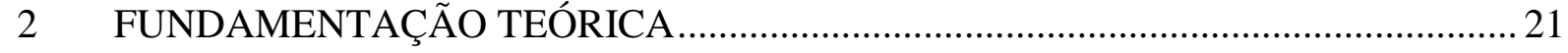

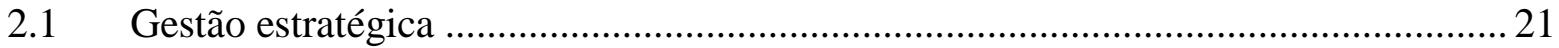

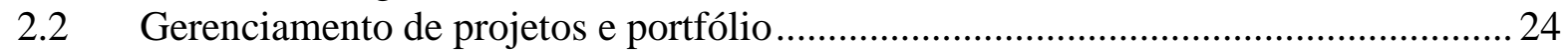

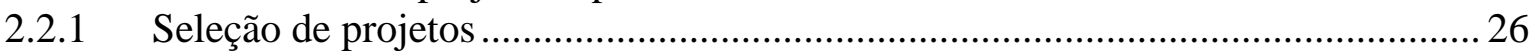

2.3 Escritórios de gerenciamento de projetos (EGP ou PMO) ….................................. 28

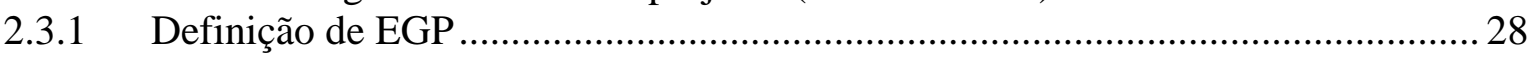

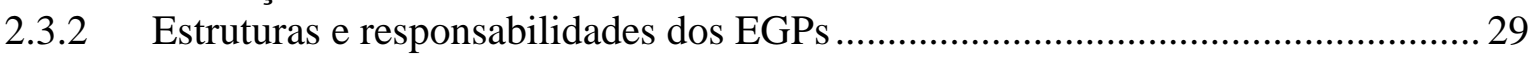

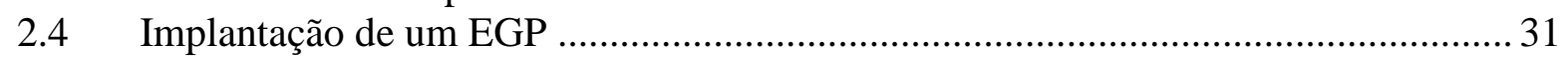

2.5 Benefícios e desafios da implantação de um EGP …….............................................. 33

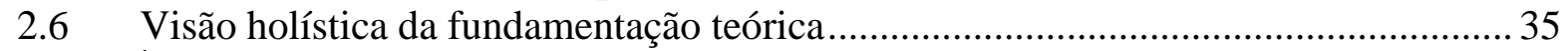

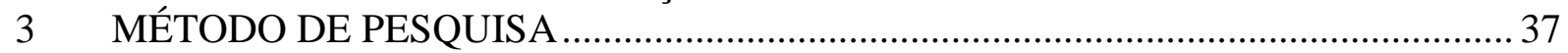

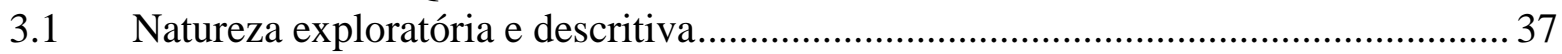

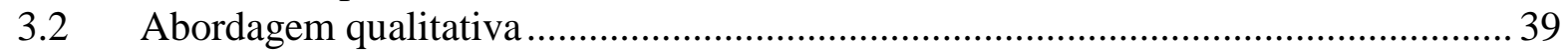

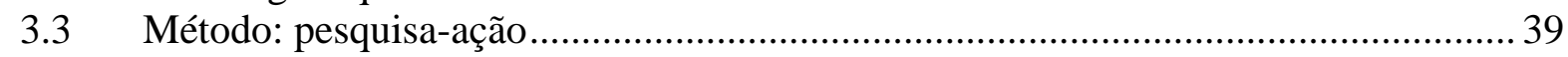

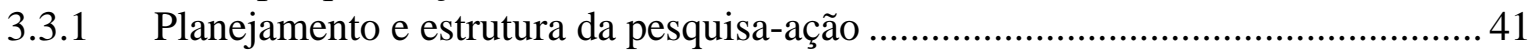

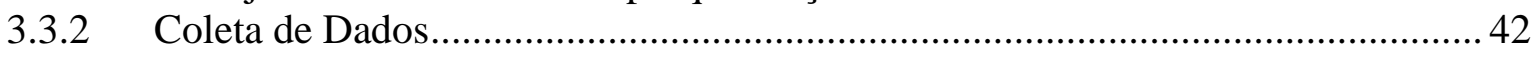

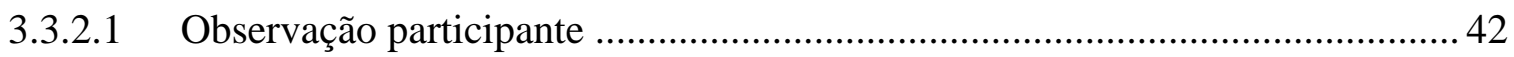

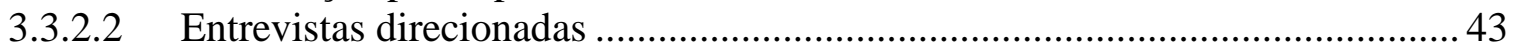

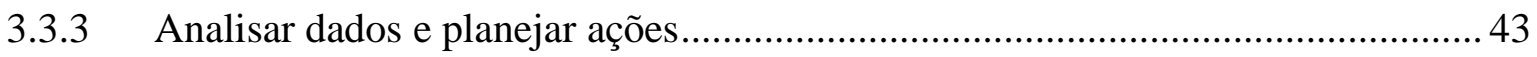

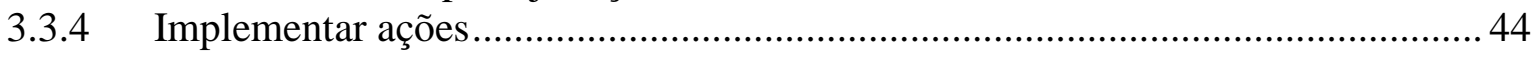

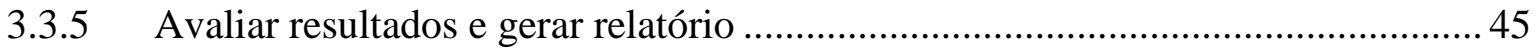

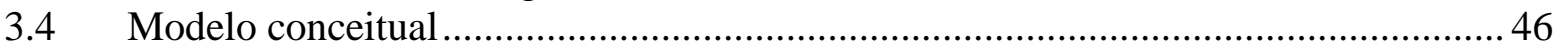

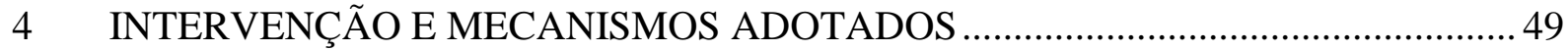

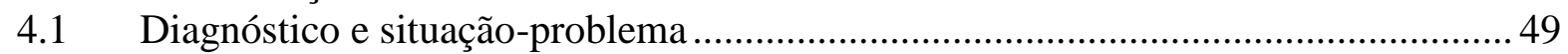

4.2 Planejamento das ações e detalhamento da intervenção ......................................... 50

4.2.1 Mapeamento dos projetos ............................................................................... 51

4.2.2 Criação de um escritório de gerenciamento de projetos e estruturação dos projetos

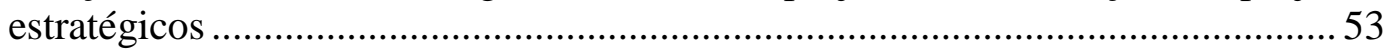

4.2.3 Sensibilização dos líderes de projeto e disseminação de uma cultura

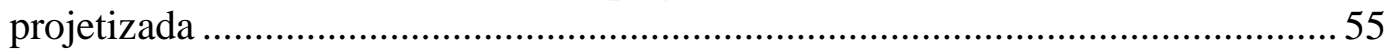

4.2.4 Acompanhamento dos projetos estratégicos e institucionalização do EGP .......... 56

4.3 Principais resultados decorrentes da proposta de intervenção ...................................57

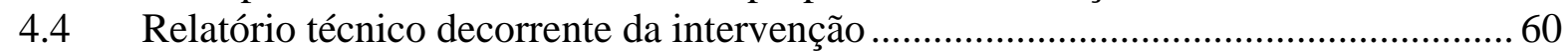

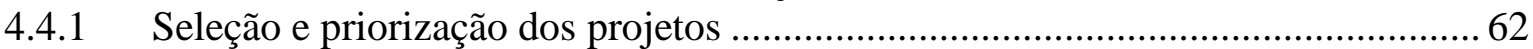

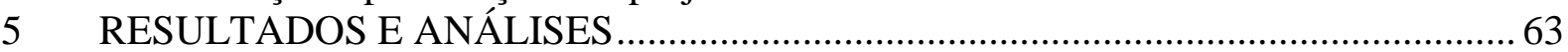




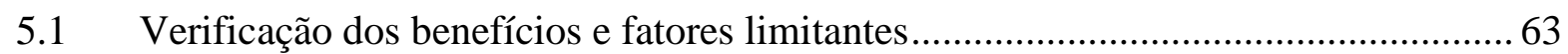

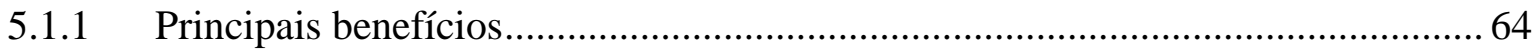

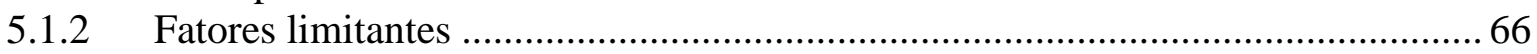

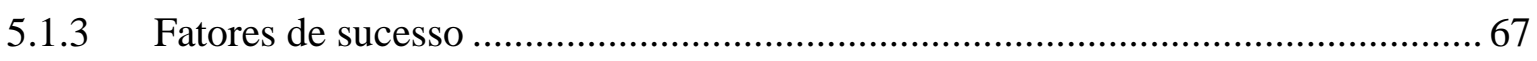

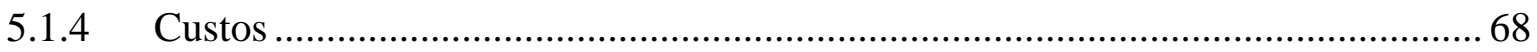

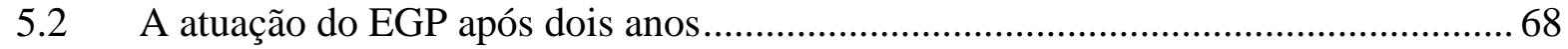

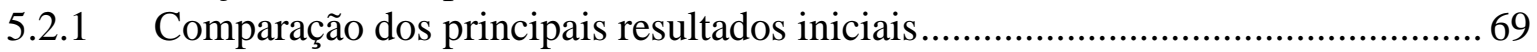

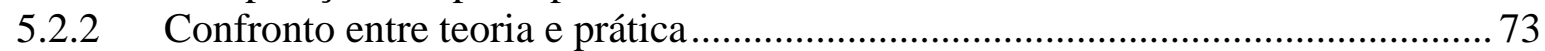

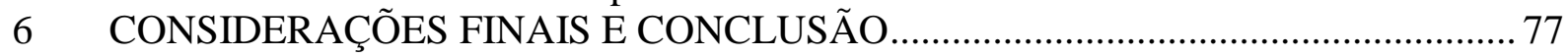

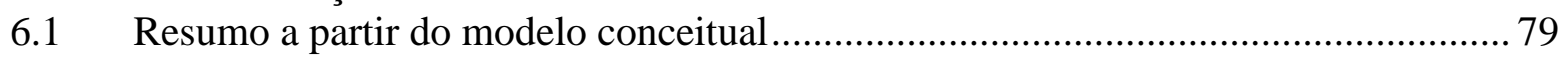

6.2 Contribuições para prática e para a academia ........................................................ 80

6.3 Limitações da pesquisa e sugestões para estudos futuros ....................................... 81

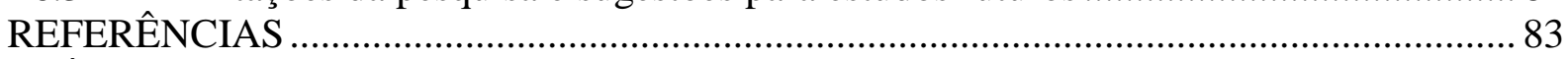

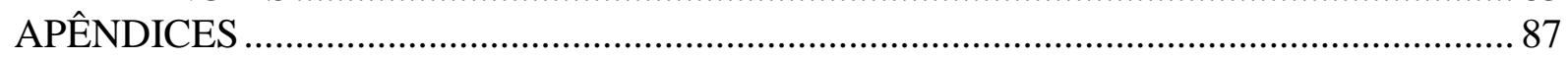




\section{LISTA DE ABREVIATURA E SIGLAS}

- EAP: Estrutura Analítica de Projetos, do Inglês.

- EGP: Escritório de Gerenciamento de Projetos.

- KPI: é a sigla para o termo em inglês Key Performance Indicator, que significa Indicador-chave de Desempenho. Esse indicador é utilizado para medir o desempenho dos processos de uma empresa e, com essas informações, colaborar para que alcance seus objetivos.

- PMBOK: Project Management Body of Knowledge, publicação de padrões globais de gerenciamento de projetos, programas e portfólio, sendo a mais popular delas o Guia do Conjunto de Conhecimentos em Gerenciamento de Projetos (Guia PMBOK®).

- PMI: Project Management Institute, associação de profissionais que focam na gestão de projetos.

- PMP: Project Management Professional, certificação de Profissional de Gerenciamento de Projetos.

- PMO: Project Management Office, em português, Escritório de Gerenciamento de Projetos. 



\section{LISTA DE TABELAS}

Tabela 1: Dimensões do gerenciamento de projetos

Tabela 2: Características da empresa estudada 13

Tabela 3: Definições de EGP 28

Tabela 4: Caracterização de Escritórios de Gerenciamento de Projetos 31

Tabela 5: Planejamento da pesquisa-ação (contexto da empresa estudada) 41

Tabela 6: Esqueleto para análise das ações implementadas 45

Tabela 7: Sumário da pesquisa-ação e resultados obtidos 46

Tabela 8: Ações propostas no plano de intervenção e literatura estudada 51

Tabela 9: Papéis e responsabilidades da Oficina de Projetos. 59

Tabela 10: Resumo do relatório técnico. 61

Tabela 11: Resultado das Entrevistas 64

Tabela 12: Papéis e responsabilidades da área de Gerenciamento e Gestão .71

Tabela 13: Comparação entre teoria e prática em relação aos benefícios de um EGP .74 



\section{LISTA DE FIGURAS}

Figura 1: Interação entre prática e teoria na confecção da dissertação 17

Figura 2: Estruturação da dissertação. 18

Figura 3: Níveis de EGP e suas funções 32

Figura 4: Visão holística da fundamentação teórica 36

Figura 5: Descrição gráfica da tipologia da pesquisa. 37

Figura 6: Relação da pesquisa exploratória com a construção dos capítulos 38

Figura 7: Estrutura para condução da pesquisa-ação 40

Figura 8: Modelo conceitual da pesquisa 47

Figura 9: Matriz de relevância estratégica dos projetos em estruturação 52

Figura 10: Exemplo de ficha de projeto 54

Figura 11: Organograma pós-implantação do EGP 57

Figura 12: Estrutura de cargos do EGP 58

Figura 13: Organograma da atual organização .70

Figura 14: Estrutura de cargos da área de Gerenciamento e Gestão .70

Figura 15: Contribuições para a prática e para a academia 80 



\section{INTRODUÇÃO}

O crescimento e a evolução das organizações está, normalmente, relacionado à execução bem-sucedida de projetos que resultam em novos produtos, serviços ou procedimentos. Gerenciamento de projetos, por conseguinte, é a principal ferramenta pela qual muitas empresas implementam seus objetivos estratégicos.

A intersecção entre gerenciamento de projetos e estratégia é um tema de suma importância no dia a dia organizacional de uma empresa, visto que o sucesso de longo prazo e a manutenção de vantagens competitivas sustentáveis podem estar diretamente relacionados à implementação de uma estratégia por meio da gestão competente de uma carteira variada de projetos (GUEDES et al., 2011).

Apesar de a literatura, usualmente, dar foco ao gerenciamento de um único projeto, a realidade das empresas indica que a cultura multi-projetos é um ponto crítico para o sucesso das organizações (UNGER; GEMÜNDEN; AUBRY, 2012).

Não obstante a relevância dos projetos nas organizações, uma das queixas mais frequentes entre os gerentes de projetos é que estes surgem quase aleatoriamente, lhes parecendo estarem desvinculados de uma estratégia coerente. Como resultado, as pessoas podem sentir que trabalham em projetos desnecessários, até mesmo com objetivos opostos à estratégia empresarial (ENGLUND; GRAHAM, 1999).

A busca atual das organizações em executar seus objetivos estratégicos, por meio de uma cultura projetizada, vem colocando o gerenciamento de projetos em pauta nas publicações recentes. Neste contexto, o PMI, Project Management Institute, fundado em 1969, é a maior associação de profissionais com foco na gestão de projetos, contando com mais de 700.000 membros ao redor do globo.

Um assunto específico que tem frequente destaque nas revistas e institutos especializados é o EGP, Escritório de Gerenciamento de Projetos, ou, em inglês, PMO, Project Management Office. Isto porque muitas empresas enfrentam problemas com a falta de organização e 
coordenação de seus projetos, impactando diretamente a execução da estratégia (RODRIGUES; RABECHINI JR.; CSILLAG, 2006).

Russo e Sgragia (2007) sintetizaram problemas comuns que são enfrentados por grandes empresas no gerenciamento de seus projetos, tais como: falta de entendimento da complexidade dos projetos, comunicação interna falha, baixa integração de elementos e áreas chaves da organização, controles inadequados, estratégia de execução de projetos ineficiente, treinamentos falhos, falta de comprometimento da liderança e dos patrocinadores.

É neste contexto que a presente dissertação tem por objetivo avaliar a implantação de um EGP, colocando-o como uma ferramenta eficaz para minimizar os problemas de gerenciamento de projetos, garantindo, assim, a execução da estratégia de longo prazo, que culmina na evolução e no crescimento da empresa.

Pela relevância do tema, tanto na dimensão acadêmica quanto na dimensão empresarial, o cerne da dissertação será analisar a implementação de um Escritório de Gerenciamento de Projetos, seus benefícios e seus fatores limitantes de sucesso.

Para tanto, os próximos subitens deste capítulo procurarão descrever: a experiência prática que motivou a dissertação (1.1), a problemática observada ao redor deste tema (1.2), a questão de pesquisa e os objetivos do trabalho (1.3), as justificativas e contribuições, tanto acadêmicas quanto práticas (1.4) e, por fim, a estruturação dos capítulos, como guia para o entendimento da dissertação (1.5).

\section{$1.1 \quad$ Relato da experiência}

A literatura de gerenciamento de projetos recentemente ampliou suas áreas de cobertura. $\mathrm{O}$ sucesso dos projetos normalmente era medido no campo operacional, por meio da conhecida tríade: custo, tempo e escopo. Contudo, a teoria de gerenciamento de projetos pode ser 
utilizada como uma poderosa ferramenta para garantir a execução da estratégia, gerando os retornos esperados pela Alta Administração ${ }^{1}$ e pelos acionistas (JUGDEV; THOMAS, 2002).

Neste contexto mais amplo, Anselmo (2009) propôs a análise do tema gerenciamento de projetos a partir de três dimensões: (i) estratégica, (ii) organizacional e (iii) operacional, conforme Tabela 1:

Tabela 1: Dimensões do gerenciamento de projetos

\begin{tabular}{|l|l|}
\hline Dimensão & Ferramenta \\
\hline Estratégica & Portfólio de Projetos \\
\hline Organizacional & PMO \\
\hline Operacional & PMBOK \\
\hline
\end{tabular}

FONTE: ANSELMO, 2009.

A dimensão estratégica é representada pelo portfólio de projetos, resultado da seleção dos projetos que serão responsáveis pela execução da estratégia empresarial. A dimensão organizacional, por sua vez, é essencialmente constituída pelo Escritório de Gerenciamento de Projetos, ou PMO, definido como a unidade da organização responsável por apoiar e estruturar os projetos selecionados. Por fim, há a dimensão operacional que é caracterizada por cada unidade de projeto da organização.

Com base nestes preceitos teóricos, o Relato da Experiência, detalhado a seguir, dará foco nas dimensões estratégica e organizacional, uma vez que está baseado na implantação de um EGP como forma de garantir a execução da estratégia empresarial.

A experiência a ser relatada ocorreu concomitantemente à execução do Mestrado Profissional, no qual busca-se aplicar a teoria na prática empresarial, dando espaço, assim, para o desenvolvimento de uma pesquisa-ação - que pôde ser implementada e ter seus resultados medidos durante o período de execução do mestrado - finalizada com a presente dissertação.

\footnotetext{
${ }^{1}$ Principais executivos responsáveis pela estratégia de uma empresa (presidente e diretores executivos).
} 


\subsubsection{Unidade de Análise}

A pesquisa-ação, cerne da presente dissertação, foi realizada em uma empresa brasileira do setor de educação básica, com mais de 5.000 funcionários e localizada em diferentes regiões do país (Sudeste, Nordeste e Centro-Oeste). O processo de crescimento da empresa ocorreu, nos últimos cinco anos, em decorrência da aquisição de diversos ativos na área de educação, tais como: editoras, escolas particulares, escolas de idiomas, sistemas de ensino e soluções tecnológicas com foco na aprendizagem. A partir da estratégia de múltiplas aquisições, a empresa passou a ser um grande conglomerado de ativos educacionais, atuando de maneira diversificada no mercado brasileiro.

Esta empresa, por consequência de seu tamanho e ativos diversificados, foi adquirida por um fundo de investimentos que iniciou um processo de transformação estratégica, decorrente da troca de controle societário. A estratégia da nova empresa - implementada pelo fundo buscava uma evolução no setor educacional, tendo como principais objetivos o crescimento de market share ${ }^{2}$, a busca de sinergia por meio da integração de seus diversos tipos de ativos e a inovação no mercado de educação básica por meio de novas propostas e produtos.

A fim de alcançar os objetivos de longo prazo, a Alta Administração (constituída pelos novos sócios, representantes do fundo de investimento) desenhou um plano estratégico, desdobrado em metas de curto e longo prazo, que deveria ser implantado por diversas áreas operacionais da empresa. É neste contexto que se verificou que a implantação de um Escritório de Gerenciamento de Projetos poderia ser uma ferramenta de gestão eficaz aos novos sócios, garantindo a execução de seu plano estratégico.

A Tabela 2 resume as principais características da empresa - unidade de análise da dissertação.

\footnotetext{
${ }^{2}$ Grau de participação de uma empresa no mercado em termos das vendas de um determinado produto; fração do mercado controlada por ela.
} 
Tabela 2: Características da empresa estudada

\begin{tabular}{|l|l|}
\hline Ramo de atividade & $\begin{array}{l}\text { Atua no setor de educação } \\
\text { (editoras, escolas particulares, } \\
\text { escolas de idiomas, sistemas de } \\
\text { ensino e soluções tecnológicas) }\end{array}$ \\
\hline Número de funcionários & Porte grande (acima de 5.000) \\
\hline Controle acionário & Fundo de investimento \\
\hline
\end{tabular}

FONTE: Elaborado pela autora.

Em consonância com o que é esperado por um Mestrado Profissional, identificou-se uma oportunidade ímpar de aplicação dos conceitos de gerenciamento de projetos, com foco na execução da estratégia, por meio de uma experiência prática que ocorreria de maneira concomitante à pesquisa teórica.

A pesquisa-ação foi possível pois seus resultados puderam ser medidos ao longo de dois anos, gerando contribuições significativas tanto para a prática empresarial, quanto para a consolidação do conceito acadêmico do Mestrado Profissional.

\subsubsection{Implantação de um Escritório de Gerenciamento de Projetos}

A partir da interação entre prática e teoria, implantou-se um Escritório de Gerenciamento de Projetos, cujo objetivo era atingir as metas propostas no plano estratégico desenhado pelos novos sócios da empresa. O EGP foi definido como uma unidade organizacional responsável por estruturar, gerenciar e implantar os projetos selecionados, a partir das premissas estabelecidas no plano estratégico.

Neste contexto, a proposta da presente dissertação é expor dois momentos distintos da experiência vivida: primeiramente, a implantação do Escritório de Gerenciamento de Projetos e, posteriormente, o acompanhamento do processo de gestão estratégica da empresa, ao longo de dois anos de prática organizacional. Por esta razão, dividiu-se a pesquisa em duas etapas, realizadas em diferentes momentos do tempo: 
- Etapa 01: implantação de um Escritório de Gerenciamento de Projetos na organização, como forma de garantir que o plano estratégico fosse estabelecido de maneira rápida e estruturada (conforme apresentado no Capítulo 4);

- Etapa 02: verificação dos resultados desta implantação após dois anos, focando em seus benefícios e fatores limitantes (conforme apresentado no Capítulo 5).

A primeira etapa teve como resultado a implantação do EGP na empresa, conforme prescrito nos fundamentos teóricos. Após dois anos desta implantação, buscou-se, então, verificar se sua existência favoreceu ou não a execução da estratégia da empresa, a partir dos benefícios e principais limitadores percebidos pelos principais executivos.

De acordo com Fischer (2005), buscou-se atuar por meio de experiências inovadoras que permitiram a reinvenção de práticas acadêmicas. A prática empresarial foi, assim, beneficiada e iluminada com as teorias apropriadas, dando luz a uma dissertação que envolveu fundamentos acadêmicos e práticas executivas em torno de uma problemática comum.

\subsection{Problemática observada}

Considerando a experiência relatada e atuando sob a teoria de gerenciamento de projetos, é válido voltar a atenção para as análises de Kendall e Rollins (apud REYCK et al., 2005). Os autores afirmam que a falta de processos e ferramentas no gerenciamento do portfólio de projetos pode gerar quatro problemas comuns nas empresas: (i) muitos projetos ativos, (ii) projetos que não adicionam valor à empresa, (iii) projetos que não estão devidamente relacionados aos objetivos estratégicos e, por fim, (iv) um portfólio de projetos desbalanceado.

Corroborando com as análises dos autores supracitados, estudos relatados por Aubry, Hobbs e Thuillier (2007) indicam que nem todas as organizações conseguem relacionar coerentemente seus projetos com a estratégia corporativa. 
A questão pode ser extrapolada e questionada, de forma mais ampla, uma vez que há inúmeros pontos a serem investigados no tema gerenciamento de projetos, tais como: por que organizações projetizadas existem? Por que organizações projetizadas diferem entre si? Como organizações projetizadas se comportam? Qual a função ou valor adicionado das unidades de projetos? O que determina o sucesso ou fracasso dos projetos nas organizações? (SÖDERLUND, 2004).

A partir desta problemática, é notável a relevância prática e teórica de um Escritório de Gerenciamento de Projetos, principalmente no momento em que há o estabelecimento de nova diretriz estratégica e, consequentemente, amplo portfólio de projetos sendo implantados sistemicamente.

Empresas que não desenvolvem projetos de maneira sistemática, apenas de forma esporádica, não enxergam a necessidade de implantação de um EGP e de uma estrutura específica de gerenciamento de projetos. Porém, se a estratégia da organização depende da boa implementação de projetos, uma abordagem não estruturada e pouco disciplinada pode conduzir a ineficiências e resultados falhos. Sendo assim, em organizações com um grande número de projetos sendo desenvolvidos e gerenciados concomitantemente, a necessidade de um EGP torna-se evidente (BOUER; CARVALHO, 2005).

Desse modo, na presente dissertação, além da implantação de um EGP, em uma empresa com grande número de projetos estratégicos em andamento, buscou-se também listar os principais benefícios gerados para a organização, assim como seus fatores limitantes, fatores de sucesso e os custos relacionados a esta estrutura. A interação teórica e prática, em torno de uma problemática comum, resultou na questão de pesquisa que foi perseguida ao longo do desenvolvimento da presente dissertação.

\section{Questão de pesquisa e objetivos do trabalho}

A questão de pesquisa que motivou a dissertação, a partir da análise conjunta da prática e da teoria, foi: 
Quais são os benefícios e fatores limitantes da implantação de um Escritório de

Gerenciamento de Projetos para a empresa em questão?

Considerando essa pergunta central, pode-se afirmar que o objetivo primário desta pesquisa foi verificar quais foram os benefícios da implantação de um EGP na execução da estratégia da empresa estudada, assim como seus principais fatores limitantes.

Os objetivos secundários da pesquisa foram:

1. Mapear o passo a passo da implantação de um Escritório de Gerenciamento de Projetos, comparando a teoria e a prática;

2. Identificar os principais fatores de sucesso e custos da implantação do EGP;

3. Descrever, após dois anos de implantação, a evolução do EGP na estrutura organizacional.

Espera-se, assim, indicar um framework $^{3}$ para implantação de um EGP, em consonância com os preceitos teóricos e práticos.

\subsection{Justificativas e contribuições}

Esta dissertação buscou contribuir tanto no âmbito acadêmico, quanto no âmbito prático empresarial. Isto foi possível por meio de uma intensa interação entre teoria e prática ao longo do processo acadêmico, que confluiu para o método de pesquisa-ação. Portanto, em primeira instância, é válido ressaltar a importância desta interação, proporcionada pelo Mestrado Profissional, que busca:

[...] adição de valor social ao mercado de trabalho e à comunidade em geral, focando a profissionalização e gestão das mais diversas formas de atividades sociais, empresariais, tecnológicas e até culturais (SILVEIRA; PINTO, 2005, p. 38).

\footnotetext{
${ }^{3}$ Arcabouço conceitual, um conjunto de conceitos usado para resolver um problema de um domínio específico.
} 
Esta soma de aspectos práticos e teóricos, com foco em problemas externos à academia que podem ser resolvidos à luz de uma metodologia de qualidade, testada dentro de rigores acadêmicos exigidos, é de grande valia a todos os envolvidos (SILVEIRA; PINTO, 2005).

Esta interação foi representada na Figura 1, que mostra o caminho percorrido para a confecção da presente dissertação:

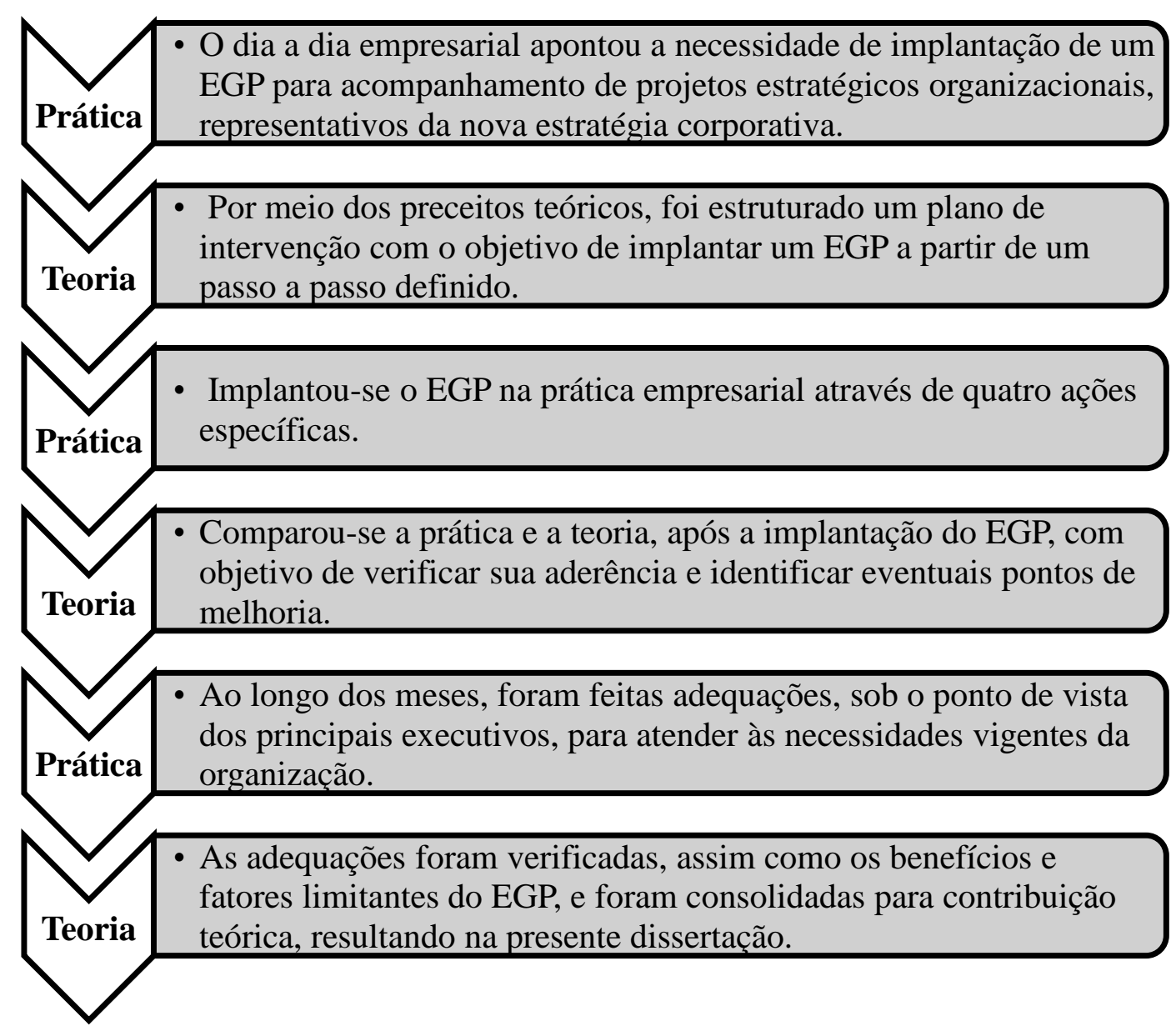

Figura 1: Interação entre prática e teoria na confecção da dissertação FONTE: Elaborado pela autora.

A interação entre prática e teoria foi de suma importância para a construção da dissertação. Deste modo, espera-se que o resultado ora apresentado seja relevante, tanto para aqueles que pesquisam com o objetivo de colocar em prática um plano de ação em suas empresas, quanto para aqueles que estudam academicamente o tema gerenciamento de projetos, em particular PMO. 


\subsection{Estruturação da dissertação}

A presente dissertação está estruturada em seis capítulos, sendo eles (Figura 2): introdução, fundamentação teórica, método de pesquisa, intervenção e mecanismos adotados, resultados e análises, e considerações finais e conclusão.

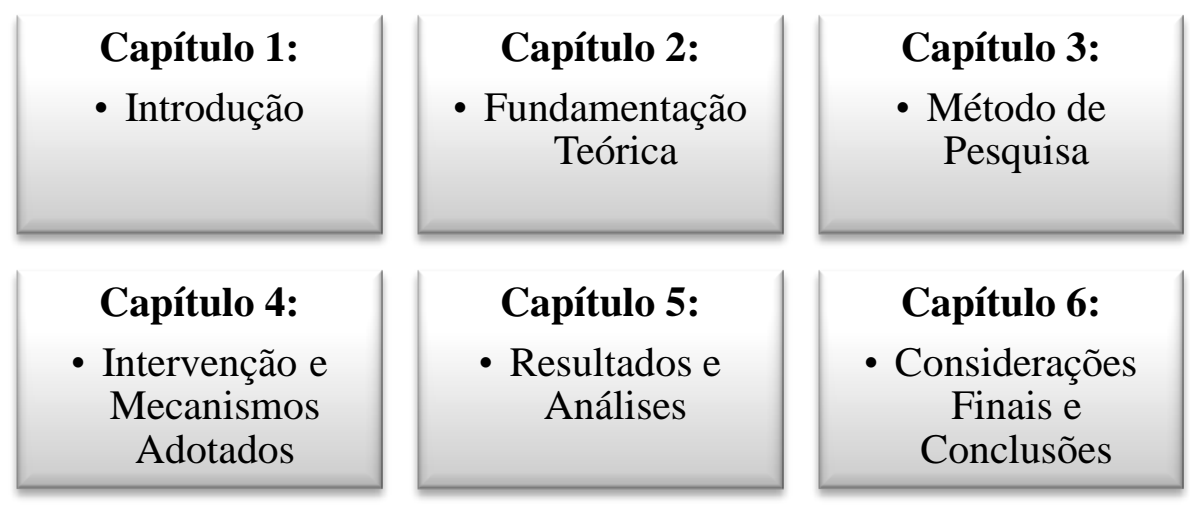

Figura 2: Estruturação da dissertação

FONTE: Elaborado pela autora

No Capítulo 1, Introdução, foram apresentados os objetivos, primários e secundários, da dissertação e da questão de pesquisa a eles relacionada: quais são os benefícios e fatores limitantes da implantação de um Escritório de Gerenciamento de Projetos? Buscou-se, nesse capítulo, o entendimento geral do que será discutido e pesquisado, a partir de conceitos teóricos que correlacionam o gerenciamento de projetos, a implantação de um Escritório de Gerenciamento de Projetos e os resultados obtidos, com base em uma visão de gestão estratégica e organizacional. A questão de pesquisa, em um Mestrado Profissional, está vinculada com o Relato de Experiência também apresentado neste capítulo.

No Capítulo 2, Fundamentação Teórica, serão descritas teorias (levando em conta os principais autores na atualidade que versam sobre esse tema) relacionadas à questão de pesquisa da dissertação. Esse capítulo será arquitetado de maneira holística e abrangente, com a finalidade de construir o embasamento teórico necessário para detalhar os principais objetivos do presente trabalho. Por esta razão, o último subitem tem como objetivo relacionar as teorias levantadas com os objetos deste trabalho, para propiciar um maior entendimento dos resultados esperados. 
No Capítulo 3, Método de Pesquisa, será descrita a metodologia utilizada para a pesquisa a partir de três aspectos (i) seu propósito ou natureza, (ii) sua forma de abordagem e (iii) seu método (pesquisa-ação). Neste capítulo serão apresentados e detalhados os procedimentos metodológicos decorrentes da aplicação do método de pesquisa escolhido. O modelo conceitual da dissertação também será apresentado neste momento da dissertação.

No Capítulo 4, Intervenção e Mecanismos Adotados, serão apresentadas as intervenções propostas na implantação do Escritório de Gerenciamento de Projetos, assim como a ligação entre os resultados obtidos e as teorias estudadas. Este capítulo é de primordial importância para cultivar os objetivos propostos pelo Mestrado Profissional.

No quinto, e penúltimo, capítulo, Resultados e Análises, serão apresentadas as percepções dos principais executivos em relação aos benefícios e fatores limitantes do Escritório de Gerenciamento de Projetos implementado. A evolução do EGP, durante os dois anos de pesquisa, também é tema de análise neste capítulo.

No último capítulo, Considerações Finais e Conclusões, serão apresentadas as principais conclusões que respondem aos objetivos primários e secundários da dissertação. Além disso, serão descritas as limitações encontradas, assim como sugeridos futuros estudos a partir dos resultados da pesquisa. Buscou-se criar um framework que possa trazer insights ${ }^{4}$ para a implantação de novos EGPs, considerando os pontos apresentados tanto pela teoria estudada, quanto pela prática vivida.

Na sequência, todo o Referencial Bibliográfico utilizado na composição da dissertação pode ser encontrado, assim como os Apêndices considerados relevantes para a construção do presente trabalho.

\footnotetext{
${ }^{4}$ Entendimento de uma causa e efeito específicos em um contexto particular.
} 



\section{FUNDAMENTAÇÃO TEÓRICA}

A fundamentação teórica foi construída a fim de que conceitos estratégicos pudessem encontrar parâmetros organizacionais e operacionais, conforme Tabela 1, baseada em Anselmo (2009).

De acordo com Jugdev e Muller (2005), na dimensão estratégica, os executivos focam a criação da estratégia, missão e valores da empresa. Estes conceitos, por sua vez, são colocados em prática, na dimensão operacional, por aqueles que implantam os planos estratégicos e criam os produtos e serviços que referendam a estratégia. Esta implantação, por sua vez, envolve práticas de gerenciamento de projetos.

Desta maneira, o objetivo primário desta fundamentação teórica foi verificar os principais preceitos teóricos tanto na dimensão estratégica, quanto na dimensão organizacional e operacional. Por conseguinte, os subitens que se seguem abordarão a Gestão Estratégica (2.1), o Gerenciamento de Projetos e Portfólio (2.2), o Escritório de Gerenciamento de Projetos (EGP ou PMO) (2.3), a Implantação de um EGP (2.4) e, por fim, os Benefícios e Desafios da Implantação de um EGP (2.5).

O último subitem deste Capítulo, por sua vez, tem como objetivo verificar a Visão Holística da Fundamentação Teórica, uma vez que a visão teórica daqueles que analisam a prática deve ser longitudinal, visto que os fenômenos interagem entre si e não se apresentam de forma pontual e isolada.

\subsection{Gestão estratégica}

A execução da estratégia é componente integral do processo de gestão estratégica e é vista como o processo que transforma a estratégia em uma série de ações para garantir que a visão, a missão e os objetivos estratégicos da organização sejam alcançados com sucesso (JOOSTE; FOURIE, 2009). 
A estratégia, uma vez que bem definida e corretamente executada, é a principal ferramenta para garantir vantagem competitiva perante o mercado e os concorrentes. Porter (1996), em um de seus artigos sobre estratégia, definiu que uma vantagem competitiva sustentável é decorrente da(o):

- Busca de uma posição competitiva singular para a empresa;

- Garantia de que as atividades operacionais estejam alinhadas e adequadas à estratégia;

- Trade-off $s^{5}$ e escolhas claras em comparação ao que os concorrentes estão ofertando no mercado; e

- Busca de sinergia das atividades a partir de um sistema único e não da visão das partes e da eficiência operacional.

Se a execução da estratégia, portanto, é um dos fatores responsáveis pela vantagem competitiva de uma empresa, é necessário dar atenção ao tema, a fim de assegurar que os níveis gerenciais e operacionais garantam a manutenção desta vantagem competitiva.

Neste contexto, Kaplan e Norton (2001) descrevem cinco ações para garantir que a estratégia seja bem executada e atinja níveis operacionais, a saber:

1. Traduzir a estratégia em termos operacionais, através do balanced scorecard ${ }^{6}$;

2. Alinhar toda a organização em torno da estratégia (entre todas as áreas e funções: financeiro, produção, comercial e marketing);

3. Fazer da execução da estratégia o trabalho do dia a dia de toda a companhia;

4. Fazer com que a estratégia seja um processo contínuo (manter a conexão com o orçamento, fazer revisões periódicas e criar um mecanismo para que existam correções rápidas de rota que se façam necessárias); e

5. Mobilizar a mudança através da liderança executiva da empresa.

\footnotetext{
${ }^{5}$ Expressão que define uma situação em que há conflito de escolha, ocorre quando se abre mão de algum bem ou serviço distinto para se obter outro bem ou serviço distinto. Custo de escolha.

${ }^{6}$ Metodologia de medição e gestão de desempenho desenvolvida pelos professores da Harvard Business School (HBS) Robert Kaplan e David Norton, em 1992.
} 
O alinhamento da estratégia com as atividades operacionais das organizações, todavia, não é uma tarefa fácil. Muitas são as empresas que enfrentam barreiras que impedem uma gestão eficaz de sua estratégia. Guedes et al. (2011, p. 78) citam algumas destas barreiras, conforme abaixo:

\section{Barreiras relacionadas à Estratégia:}

- Quando a definição da estratégia é pobre ou vaga;

- Quando a execução de uma estratégia é conflitante com a estrutura de poder vigente;

- Quando não existe um guia ou modelo que possa orientar os esforços de implementação e execução da estratégia.

\section{Barreiras relacionadas à Comunicação e ao Gerenciamento de Times:}

- Quando há pouca habilidade em gerir a mudança de maneira efetiva para ultrapassar resistências internas;

- Quando há falta de comunicação das responsabilidades associadas à execução da estratégia (em relação à tomada de decisões ou ações ligadas à implementação);

- Quando o compartilhamento de informações é pobre ou inadequado entre indivíduos ou unidades de negócio responsáveis pela execução da estratégia;

- Quando há falta de sentimento de propriedade (comprometimento) de empregadoschave com a estratégia ou planos de execução.

Estas barreiras estão alinhadas com as conclusões de Jooste e Fourie (2009) que enfatizam que a má compreensão da estratégia pelos empregados-chaves e a comunicação ineficaz da estratégia são as barreiras mais relevantes para a implementação de uma estratégia bemsucedida.

Sob a ótica da presente dissertação, uma das formas para minimizar estas barreiras é a implantação da estratégia por meio de projetos bem definidos. Em consonância com esta visão, Dinsmore (2003, p. 33) indica que os projetos bem-sucedidos exigem:

[...] o preenchimento da lacuna entre a visão da empresa e os projetos em andamento, o que por sua vez requer coordenação entre estratégias corporativas, o alinhamento geral dos projetos, o alinhamento de projetos específicos e a implementação de projetos. 
Russo e Sbragia (2007) corroboram com esta visão uma vez que acreditam que a estratégia (que busca alavancar e perpetuar os negócios a partir de resultados satisfatórios), em sua maioria, é realizada por meio de projetos, caracterizados como um esforço temporário na geração de um produto, serviço ou resultado exclusivo.

Fica evidente que o alinhamento estratégico dos projetos se torna uma obrigação para as empresas. Este alinhamento, por sua vez, pode acontecer por meio do gerenciamento de projetos, incluindo gerenciamento de portfólio, que é considerado uma maneira de implementar a estratégia. Por conseguinte, a tradução da estratégia em programas ou projetos é um processo vital no contexto apresentado (AUBRY; HOBBS; THUILLIER, 2007).

O próximo subitem deste capítulo, portanto, versará sobre o tema de gerenciamento de projetos e portfólio.

\subsection{Gerenciamento de projetos e portfólio}

O portfólio de projetos pode ser considerado uma das melhores formas de representação da estratégia, conforme dimensão apresentada na Tabela 1. Por esta razão, tem grande importância no tema de gerenciamento de projetos.

Em consonância com a literatura apresentada no subitem anterior e de acordo com Reyck et al. (2005), diversos artigos discutem sobre as condições pré-existentes nas empresas para o gerenciamento e seleção de uma carteira de projetos e, dentre elas, a estratégia organizacional novamente é destacada.

Além disso, outros elementos, de igual importância, devem estar presentes na escolha do portfólio (REYCK et al., 2005), tais como:

- Visão centralizada do portfólio de projetos;

- Análises financeiras robustas;

- Análises de risco;

- Interdependência dos projetos em relação a recursos, atividades e resultados; 
- Priorização, alinhamento e seleção de projetos;

- Análise das limitações existentes (por exemplo: recursos humanos, habilidades destes recursos, orçamento e infraestrutura);

- Realocação dinâmica do portfólio; e

- Necessidade de um software especializado.

As organizações devem ter clareza de suas estratégias vigentes, que - por sua vez - devem estar comunicadas a todos os seus departamentos e alinhadas com a seleção dos principais projetos a serem desenvolvidos em diversos níveis. O gerenciamento de projetos apenas é eficaz no momento em que a estratégia da corporação está desdobrada em uma escolha de portfólio de projetos coerente e corretamente operacionalizados por intermédio de uma gestão de carteira de projetos adequada (RABECHINI JR.; MAXIMIANO; MARTINS, 2005).

Os autores Rabechini Jr., Maximiano e Martins (2005), Crawford (2002) e Ghasemzadeh e Archer (1999) sintetizam processos e procedimentos gerenciais de modo a apresentar um passo a passo para criação de um portfólio de projetos; matéria intimamente ligada com o gerenciamento de portfólios:

1. Identificação de projetos: a partir da consideração dos aspectos estratégicos e táticos dos ambientes internos e externos e da consideração dos projetos em andamento na empresa.

2. Alinhamento das oportunidades às estratégias e à organização: identificação e seleção de critérios de avaliação para seleção de projetos ou programas (novos e em andamento); busca por critérios para avaliação e hierarquização destes projetos/programas.

3. Avaliação de investimentos e recursos: importantes pontos de decisão ou filtros que levam em consideração aspectos financeiros dos projetos, tais como seu custo e retorno ao acionista.

4. Desenvolvimento de portfólio: avaliação dos projetos dentro do contexto de carteira, relacionando-os uns aos outros; busca por priorização entre os projetos, 
com possibilidades de exclusão ou inclusão de recursos. O portfólio pode também ser um instrumento para revisão do escopo dos projetos.

5. Gerenciamento de Portfólio: desenvolvimento da estruturação dos projetos em termos de escopo, prazos e custos; acompanhamento do andamento, liberação de recursos, comunicação e outras ações gerenciais para garantir a execução dos projetos escolhidos.

Dentre todas as ações sugeridas pelos autores, o processo de seleção de projetos estratégicos ocorre em quatro dos cinco itens do passo a passo, demonstrando sua relevância para o gerenciamento de portfólio. Por este motivo, o próximo subitem dedicará sua atenção exclusivamente ao tema da seleção dos projetos.

\subsubsection{Seleção de projetos}

Apesar da relevância estratégica do tema seleção de projetos, muitas vezes esta seleção, que deveria ser feita de forma objetiva e criteriosa, é prejudicada e os projetos selecionados podem não refletir efetivamente os direcionamentos estratégicos da organização.

De acordo com Ghasemzadeh e Archer (2000), diversos são os fatores que influenciam a má seleção de projetos, entre eles:

- A existência de muitos projetos e com objetivos conflitantes entre si;

- Portfólio de projetos com objetivos meramente qualitativos;

- Não mensuração correta de riscos e incertezas;

- Alta interdependência de projetos; e

- Grande número de portfólios factíveis, dificultando a priorização.

Por esta razão, há um interesse das organizações em construir critérios mais claros, objetivos e matemáticos quando se trata do tema seleção de projetos. Acredita-se que, em muitos casos, a tomada de decisão é resultante de um processo cognitivo, baseado em critérios tangíveis e intangíveis (VARGAS, 2010). 
Cooper, Edgett e Kleinschmit (1998) resumem o tema, de maneira muito eficiente, dizendo que a carteira de projetos selecionados é a maior expressão da estratégia.

A partir das inferências de Vargas (2010), Meade e Presley (2002), Alberton et al. (2004) e Mustafa e Al-Bahar (1991), resumiu-se os principais critérios utilizados pelas empresas em seu processo decisório; critérios gerados a partir das ferramentas escolhidas para sua mensuração:

- Critérios financeiros: retorno do investimento, lucro operacional, valor presente líquido, período de retorno, taxa financeira de custo/benefício, taxa interna de retorno;

- Critérios estratégicos: indicadores balanceados de desempenho (balanced scorecard);

- Riscos e Ameaças: matriz de risco;

- Urgência: cronogramas;

- Comprometimento das partes interessadas: avaliações qualitativas das partes interessadas; e

\section{- Conhecimento técnico.}

O detalhamento dos critérios acima está minuciosamente apresentado no Apêndice 01 da dissertação.

Retomando os conceitos de Anselmo (2009), a seleção de projetos e a definição do portfólio estão relacionadas com a dimensão estratégica da empresa. Uma vez os projetos selecionados, eles devem ser apoiados e orientados organizacionalmente - tema a ser detalhado no subitem Escritório de Gerenciamento de Projetos (EGP ou PMO). 


\subsection{Escritórios de gerenciamento de projetos (EGP ou PMO)}

Esta seção tem dois objetivos primários: definir o que é um Escritório de Gerenciamento de Projetos (EGP ou PMO) (2.3.1) e apontar suas possíveis estruturas organizacionais e respectivas responsabilidades (2.3.2).

Para o primeiro item, escolheu-se a definição apresentada pelos autores Maximiano e Anselmo (2006) e, para o segundo, as definições apresentadas pelo PMI (2013) como principais norteadores da presente dissertação.

\subsubsection{Definição de EGP}

A definição conceitual de EGP escolhida para a presente dissertação é aquela adotada por Maximiano e Anselmo (2006, p. 395-396):

\footnotetext{
O EGP é definido, portanto, como a unidade organizacional formalmente estabelecida que tem a responsabilidade de: definir, uniformizar e defender padrões, processos, métricas e ferramentas; oferecer serviços de gerenciamento, treinamento e documentação; garantir o alinhamento das iniciativas à estratégia organizacional; confeccionar relatórios de progresso e acompanhamento e enviá-los para os patrocinadores.
}

Todavia, existem outras definições que podem ser consideradas para definir EGP. Martins, Moura e Mesquita (2011, p. 31) sumarizaram algumas destas definições, abaixo representadas na Tabela 3.

Tabela 3: Definições de EGP

\begin{abstract}
Definição de EGP
Estrutura que favoreça o plano estratégico da organização e torne possível maximizar o cumprimento de seus objetivos; que aproxime a concepção da estratégia, desenvolvida pela alta administração, de seu braço executor.

Unidades ou estruturas centralizadoras do desdobramento da estratégia para toda a organização, onde se dá o alinhamento e a sustentação ativa do planejamento estratégico da organização.
\end{abstract}

\section{Autores}

Dinsmore, 2003

Kezner, 2002;

King, 1993

FONTE: Adaptado de MARTINS, MOURA e MESQUITA, 2011. 


\subsubsection{Estruturas e responsabilidades dos EGPs}

De acordo com PMI (2013), existem cinco diferentes estruturas que comportam o conceito de Escritório de Gerenciamento de Projetos:

1. EGP de Unidade Organizacional, EGP de Unidade de Negócio, EGP de Divisão, EGP de Departamento: estrutura que tem por objetivo apoiar uma unidade de negócio ou divisão da empresa, por meio de serviços como gerenciamento de portfólio, governança, suporte operacional a projetos e utilização de recursos financeiros e humanos.

2. EGP de Projeto Específico, Escritório de Projeto, Escritório de Programa: estrutura que atua como uma entidade temporária para apoiar um projeto ou programa específico. Suas atividades têm por objetivo sustentar e apoiar as equipes dos projetos por meio de: gerenciamentos de dados, coordenação de programas de governança, realização de relatórios e atividades administrativas.

3. Escritório de Suporte a Projetos, Serviços ou Controles: estrutura que apoia continuamente o gerenciamento de projetos, programas e portfólio de toda a organização. É responsável pela governança dos projetos, processos, práticas e ferramentas, fornecendo apoio administrativo para as entregas dentro de seu domínio e atuação.

4. EGP de Empresa, Organização, Estratégico, Corporativo, Portfólio, Global: estrutura que representa o nível mais elevado de EGP nas organizações. É responsável pelo alinhamento dos projetos com a estratégia corporativa e pela implantação da governança adequada. Executa funções de planejamento de portfólio para garantir o alinhamento e a coerência com a estratégia.

5. Centro de Excelência, Centro de Competências: estrutura que apoia o trabalho das equipes de projetos organizando as metodologias, padrões e ferramentas para possibilitar uma melhor entrega. Desta maneira, aumenta a capacidade da 
organização de executar projetos por meio de boas práticas e de um ponto centralizador para os gerentes de projetos.

As principais responsabilidades dos EGPs definidas pelo PMI (2013) são:

- Definição de metodologias, métricas e processos;

- Gerenciamento da entrega dos projetos, por meio de: gerenciamento de recursos, cronograma, custo, escopo, riscos, envolvidos e partes interessadas, comunicação e integração entre outros projetos e outras áreas da empresa;

- Gerenciamento de Portfólio, por meio de: priorizações, alinhamento estratégico, alocação de recursos, análise de oportunidades e investimentos, gerenciamento de riscos correlacionados, realização de relatórios;

- Gerenciamento de Talentos, por meio de: alocação de recursos, treinamentos, definição de planos de carreira, desenvolvimento de habilidades e competências através de certificações e qualificações;

- Gerenciamento de Desempenho e Governança, por meio de: relatórios de desempenhos, desenvolvimento de métricas e KPIs e acompanhamento financeiro;

- Gerenciamento de Mudanças Organizacionais, buscando a satisfação dos clientes e partes relacionadas, gerenciando as resistências e promovendo uma boa comunicação;

- Administração e Suporte dos projetos, por meio de: ferramentas e consultorias especializadas;

- Gerenciamento do Conhecimento, definindo políticas de disseminação de boas práticas e gerenciando e garantindo a propriedade intelectual; e

- Gerenciamento do Planejamento Estratégico, confirmando as prioridades estratégicas, alinhando os projetos com os objetivos da empresa, monitorando a coerência e analisando novas oportunidades.

Martins, Moura e Mesquita (2011, p. 33-34), assim como PMI (2013), acreditam que há uma variedade de possibilidades para a implantação de um EGP que está essencialmente correlacionada com a maturidade da organização em gestão de projetos. 
Bridges e Crawford (2002) ainda ressaltam que o tipo de EGP e suas funções podem ser adequados de acordo com o tipo de carteira a ser atendida (determinada pelo número de projetos e sua origem), as expectativas da organização em relação às entregas destes projetos e o seu posicionamento hierárquico na empresa.

A Tabela 4 busca sintetizar a variedade de EGPs, levando em conta as variáveis: tipo de carteira, demanda organizacional e posicionamento hierárquico-funcional.

Tabela 4: Caracterização de Escritórios de Gerenciamento de Projetos

\begin{tabular}{|c|c|c|c|}
\hline $\begin{array}{c}\text { Variável de } \\
\text { Configuração }\end{array}$ & Nível 01 & Nível 02 & Nível 03 \\
\hline Tipo de Carteira & - Um único projeto & $\begin{array}{l}\text { - Portfólio de } \\
\text { projetos do } \\
\text { departamento ou } \\
\text { divisão } \\
\text { - Projetos especiais } \\
\text { entre áreas }\end{array}$ & $\begin{array}{l}\text { - Portfólio de } \\
\text { projetos da } \\
\text { organização }\end{array}$ \\
\hline $\begin{array}{l}\text { Demanda } \\
\text { Organizacional }\end{array}$ & $\begin{array}{l}\text { - Cumprir metas e } \\
\text { cronogramas } \\
\text { - Gerar base de } \\
\text { conhecimento }\end{array}$ & $\begin{array}{l}\text { - Coordenar e } \\
\text { integrar recursos, } \\
\text { reportes, controles e } \\
\text { requisições } \\
\text { - Garantir } \\
\text { consistência do } \\
\text { processo entre os } \\
\text { projetos } \\
\text { - Consolidar e } \\
\text { reportar } \\
\text { informações, } \\
\text { controles, } \\
\text { orçamentos }\end{array}$ & $\begin{array}{l}\text { - Ser um centro de } \\
\text { excelência em GP } \\
\text { - Fornecer uma } \\
\text { visão integrada dos } \\
\text { projetos do negócio } \\
\text { - Promover o } \\
\text { alinhamento dos } \\
\text { projetos com o } \\
\text { plano estratégico da } \\
\text { organização }\end{array}$ \\
\hline $\begin{array}{l}\text { Posicionamento } \\
\text { Hierárquico-Funcional }\end{array}$ & $\begin{array}{l}\text { - Em nível do } \\
\text { desenvolvimento } \\
\text { do projeto }\end{array}$ & $\begin{array}{l}\text { - Departamento ou } \\
\text { divisão }\end{array}$ & - Diretoria \\
\hline
\end{tabular}

FONTE: MARTINS, MOURA e MESQUITA, 2011, p. 33-34.

\subsection{Implantação de um EGP}

Esta seção tem como principal objetivo detalhar a teoria sobre a implantação de um EGP. Para isso, a fim de corroborar com a definição de EGP feita por Maximiano e Anselmo 
(2006), resumiu-se abaixo a visão dos autores sobre sua forma de atuação, em consonância com PMI (2013) e Bridges e Crawford (2002).

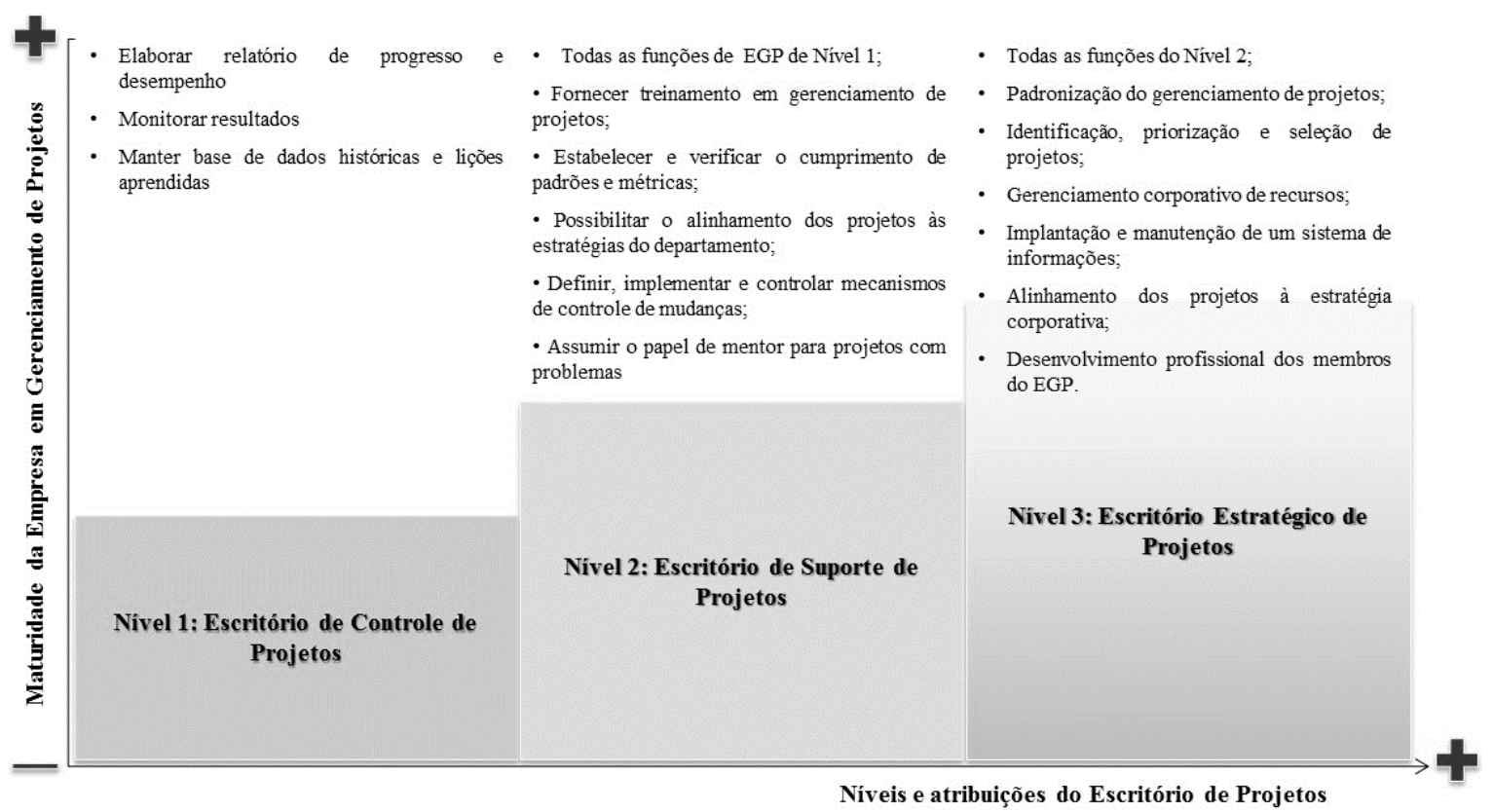

Figura 3: Níveis de EGP e suas funções

FONTE: Adaptado de MAXIMIANO e ANSELMO, 2006.

A Figura 3 foi construída com base nas teorias estudadas e apresentada na organização (unidade de análise da pesquisa-ação) como primeiro passo para a construção de um EGP na prática empresarial $^{7}$.

A figura indica que quanto maior a maturidade da empresa em gerenciamento de projetos, maior o nível de responsabilidades atribuídas ao EGP, visto que projetos em níveis diferentes de maturidade, devem ser acompanhados de maneira distinta. Para a empresa estudada, foi proposto um Escritório de Suporte de Projetos.

Posteriormente, uma vez definido o escopo, são cinco as etapas para a criação de um EGP, de acordo com Martins et al. (2005, p. 408):

\footnotetext{
${ }^{7}$ Figura retirada de uma apresentação para a Alta Administração no momento da implantação do EGP (evidência de coleta de dados durante o processo de pesquisa-ação).
} 
1. Evidenciar a importância da mudança e o senso de urgência junto aos membros da organização;

2. Identificar possíveis grupos de resistência e apresentar a estes grupos os benefícios da mudança proposta;

3. Buscar um patrocinador influente e desenvolver coalizões com membros da empresa;

4. Estabelecer quais as contribuições do EGP para atingir a visão do futuro da organização; e

5. Elaborar o plano para implantação do EGP e divulgá-lo à organização.

Um dos grandes desafios na implementação de um EGP é a resistência interna, uma vez que este representa uma mudança cultural e depende do envolvimento das pessoas para que seja bem-sucedido. Porém, a disseminação de uma cultura projetizada requer tempo (MARTINS et al., 2005). Apesar disso, Crawford (2002) sugere que a implantação ocorra rapidamente, mostrando seus primeiros resultados em 6 meses, a fim de institucionalizar o EGP.

Neste contexto, é possível afirmar que a disseminação da cultura de projetos tem suma importância no processo de implementação de um EGP. Patanakul e Milosevic (2009) acreditam que em uma empresa com multi-projetos a cultura organizacional deve enfatizar o comprometimento, a comunicação, o trabalho em equipe e a recompensa por resultado.

A implantação de um EGP traz grandes desafios internos, porém possui benefícios de extrema relevância para a empresa que opta por esta ferramenta como forma de alinhamento de seus projetos à estratégia organizacional. O próximo subitem deste capítulo é dedicado ao estudo dos benefícios e desafios desta implantação.

\subsection{Benefícios e desafios da implantação de um EGP}

Cooper, Edgett e Kleinschmit (1998), em seu livro, sintetizam os principais benefícios e desafios da gestão de portfólios e, consequente, implantação de um EGP na empresa. São oito os benefícios citados pelos executivos, em uma pesquisa feita pelo autor: 
1. Criação de uma base comum para a discussão, busca por disciplina e consistência no gerenciamento dos projetos;

2. Estabelecimento de foco e concentração em grandes projetos e projetos inovadores;

3. Busca por uma melhor adequação estratégica, correlacionando coerentemente estratégia e carteira de projetos;

4. Auxílio no equilíbrio entre os projetos de curto e longo prazo;

5. Foco e concentração nos poucos projetos que mais valem à estratégia da organização, adicionando mais valor;

6. Auxílio no go-to-market ${ }^{8}$ de maneira mais aprimorada;

7. Unificação de suportes e níveis estratégicos da empresa; e

8. Melhoria no processo de acompanhamento do planejamento estratégico.

Por outro lado, os desafios mais significativos que estão no topo das preocupações ${ }^{9}$ da Alta Administração das empresas são:

1. Criação de um clima positivo à cultura projetizada e garantia de que os métodos adotados para o gerenciamento de projetos sejam assegurados;

2. Garantia da melhor alocação de recursos, por meio de uma seleção de projetos coerente e um balanceamento de projetos adequado à estratégia organizacional;

3. Equilíbrio entre os projetos de longo prazo e curto prazo;

4. Utilização de premissas e estimativas coerentes com a realidade, por exemplo, na projeção de mercados, volumes, custos, entre outros;

5. Conexão da estratégia com a carteira de projetos a ser gerenciada;

6. Garantia do melhor equilíbrio e alocação de recursos entre unidades de negócios, divisões e tecnologias disponíveis;

7. Busca pelo melhor equilíbrio e envolvimento de diferentes áreas, níveis e funções; e

8. Utilização de métricas e ferramentas financeiras mais críveis.

Apesar dos desafios do gerenciamento de carteiras, Cooper, Edgett e Kleinschmit (1998) ressaltam que esta prática é de extrema importância, pois: maximiza o retorno do investidor;

\footnotetext{
${ }^{8}$ Plano estratégico de uma organização, utilizando seus recursos externos e internos, para entregar a sua proposta única de valor aos clientes, alcançando assim uma vantagem competitiva.

${ }^{9}$ Desafios e benefícios ranqueados de acordo com a frequência de menções (comentários top-of-mind, referindose a marca, produto ou conceito mais lembrado espontaneamente.).
} 
maximiza a produtividade da empresa, auxiliando na conquista de metas; é utilizada para manutenção da posição competitiva da empresa (aumento de vendas e market share); aloca de maneira eficiente recursos escassos; proporciona a ligação entre seleção de projetos e estratégias organizacionais; auxilia na comunicação das prioridades da organização (tanto vertical como horizontalmente) e, por fim, melhora a objetividade na seleção de projetos.

O PMI (2013) corrobora com esta visão e adiciona algumas ações para garantir que os principais impactos positivos da implantação de um EGP permeiem a cultura empresarial. As principais estratégias para a manutenção da boa implantação são:

- Criação de uma cultura organizacional de gerenciamento de projetos;

- Avaliação contínua do EGP (importância do feedback constante entre as partes relacionadas); e

- Evolução e melhorias por meio do gerenciamento de conhecimento e gerenciamento de mudanças.

\subsection{Visão holística da fundamentação teórica}

A estratégia empresarial pode ser desmembrada em um ou mais projetos (portfólio de projetos) que quando executados e operacionalizados corretamente, levam aos resultados esperados e traçados pela estratégia empresarial.

Apesar de a Fundamentação Teórica ser construída a partir de um funil, é importante ressaltar que na experiência prática os conceitos teóricos interagem entre si, encontram barreiras e limitadores, como vistos previamente, e devem ser analisados de maneira horizontal e constante.

A Figura 4 é uma simplificação teórica que está sendo utilizada como objetivo ilustrativo, buscando situar a questão de pesquisa dentro da complexidade do tema, com base nas dimensões de Anselmo (2009). 


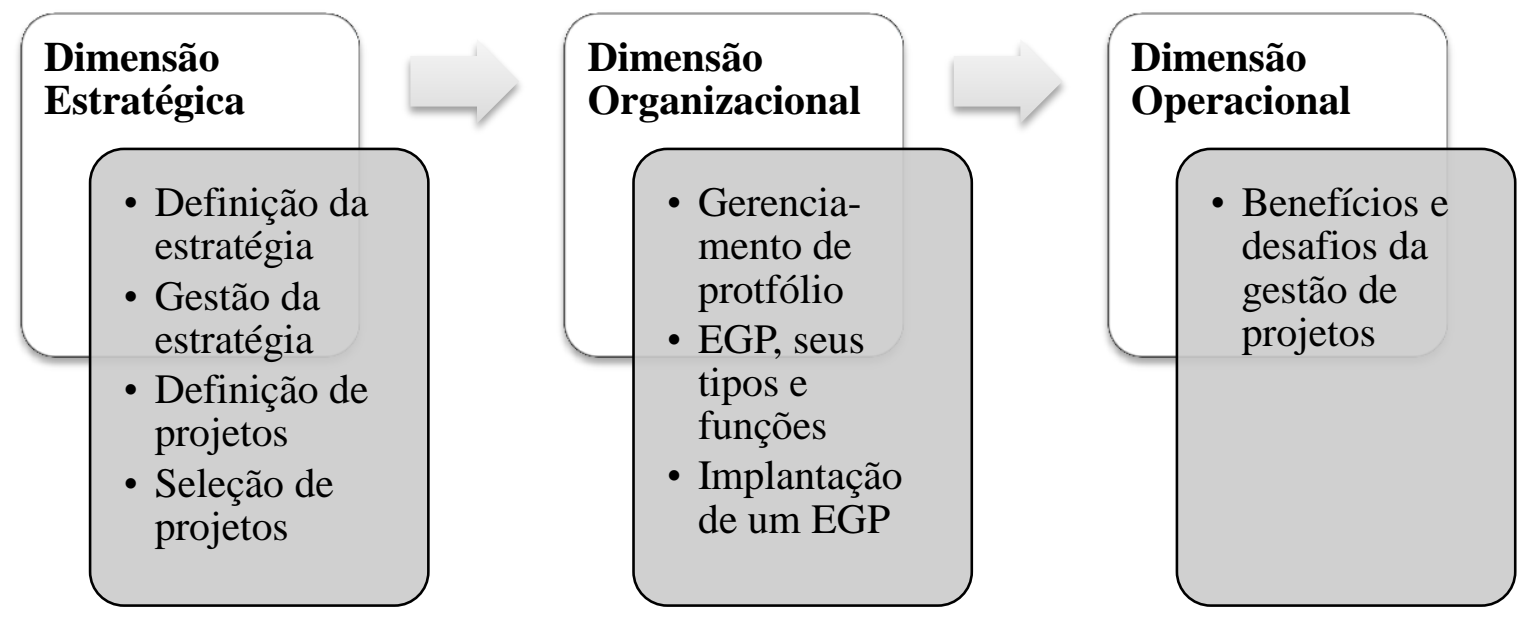

Figura 4: Visão holística da fundamentação teórica FONTE: Adaptado de ANSELMO, 2009.

A questão da pesquisa permeia os temas EGP, seus tipos e funções; implantação de um EGP; seus benefícios e desafios - estando as intervenções, mecanismos e resultados desta dissertação totalmente correlacionados com as teorias estudadas, principalmente a partir do item 2.3 da Fundamentação Teórica. 


\section{MÉTODO DE PESQUISA}

O presente capítulo tem por objetivo apresentar a metodologia do trabalho que será explanada sob três aspectos: seu propósito ou natureza (3.1), sua forma de abordagem (3.2) e seu método (3.3), conforme Figura 5.

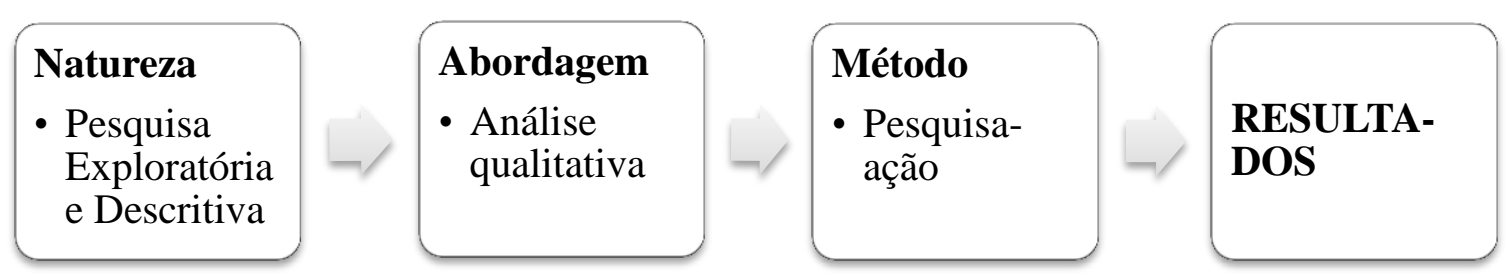

Figura 5: Descrição gráfica da tipologia da pesquisa

FONTE: Elaborado pela autora

Além disso, este capítulo também apresenta o Modelo Conceitual, em seu último subitem (3.4), como um guia de entendimento antes da apresentação das intervenções e resultados da dissertação.

\subsection{Natureza exploratória e descritiva}

Com relação à sua natureza, a presente dissertação é uma pesquisa de caráter exploratório e descritivo.

De acordo com Pinsonneault e Kraemer (1993), a pesquisa exploratória tem como objetivo familiarizar e identificar conceitos iniciais de um tópico, permitindo a descoberta de novas possibilidades e dando ênfase em como estes conceitos podem ser medidos.

Neste trabalho, é possível verificar que a pesquisa exploratória foi apresentada no Capítulo 2 (Fundamentação Teórica) no qual se procurou entender melhor o contexto teórico que abrange o tema de gerenciamento de projetos e seus principais desdobramentos (seleção de projetos, EGP, tipos e responsabilidades do EGP, implantação de um EGP, seus principais benefícios e desafios). 
Os itens estudados na Fundamentação Teórica foram abaixo correlacionados com a construção da dissertação, através da ligação entre seus capítulos, conforme representado na Figura 6.

\subsection{Gestão estratégica}

\begin{tabular}{|c|c|c|}
\hline \multicolumn{2}{|c|}{ Relato da Experiência (1.1) } & Problemática Observada (1.2) \\
\hline 2.2 Gerenciamento $\mathbf{d}$ & jetos e portfólio & \\
\hline $\begin{array}{l}\text { Relato da Experiência } \\
\text { (1.1) }\end{array}$ & $\begin{array}{l}\text { Problemática Observada } \\
(1.2)\end{array}$ & $\begin{array}{l}\text { Detalhamento da } \\
\text { Intervenção (Cap.4) }\end{array}$ \\
\hline
\end{tabular}

\subsection{Escritório de gerenciamento de projetos (EGP ou PMO)}

\begin{tabular}{|l|l|l|}
\hline $\begin{array}{l}\text { Relato da Experiência } \\
(1.1)\end{array}$ & $\begin{array}{l}\text { Detalhamento da } \\
\text { Intervenção (Cap. 4) }\end{array}$ & $\begin{array}{l}\text { Resultados e Análises } \\
\text { (Cap. 5) }\end{array}$ \\
\hline
\end{tabular}

\subsection{Implantação de um EGP}

Detalhamento da Intervenção (Cap. 4)

\subsection{Benefícios e desafios da implantação de um EGP}

Resultados e Análises (Cap. 5)

Figura 6: Relação da pesquisa exploratória com a construção dos capítulos FONTE: Elaborado pela autora.

A pesquisa descritiva é dirigida ao entendimento de certos fenômenos (situações, eventos, atitudes, opiniões etc.), com o objetivo de verificar se a percepção dos fatos está ou não de acordo com a realidade percebida (FREITAS et al., 2000). 
A pesquisa descritiva desta dissertação foi abordada de maneira qualitativa e seus resultados podem ser encontrados nos Capítulos 4 e 5. A abordagem qualitativa utilizada será exposta no subitem a seguir, possuindo alta correlação com o Relato da Experiência.

\subsection{Abordagem qualitativa}

Os trabalhos de natureza qualitativa, de acordo com Godoy (1995), têm:

- O ambiente natural como fonte direta de dados e o pesquisador como instrumento fundamental da pesquisa;

- Caráter descritivo, ou seja, a coleta de dados aparece através de transcrições de entrevistas, anotações, gravações e observações do campo;

- Como fonte de dados, a perspectiva e o ponto de vistas dos participantes, que devem ser capturados com precisão pelo pesquisador; e

- Enfoque mais amplo e abstrato, construindo seu quadro de conclusões a partir das coletas e análises de dados (diferente do enfoque quantitativo que parte de hipóteses e busca evidências numéricas para corroborar ou negar tais suposições).

Por conseguinte, considerando a natureza qualitativa da dissertação, esta coleta de dados foi feita sob o método pesquisa-ação, por meio de técnicas como planos de intervenções, entrevistas em profundidade e observação participativa.

\subsection{Método: pesquisa-ação}

De acordo com Coughlan e Coughlan (2002), diversas características definem pesquisa-ação: pesquisa em ação (em contraposição com pesquisa sobre a ação), pesquisa participativa, pesquisa em ação no momento em que ocorre, pesquisa com uma sequência de eventos ou uma proposta de solução de um problema. Maccari et al. (2008) ainda indicam que a pesquisa-ação, além de auxiliar a reflexão e implementar uma ação, também contribui para enriquecer e testar referenciais teóricos. 
Coughlan e Coughlan (2002) e Mello et al. (2012) sugerem que a execução de uma pesquisaação siga um protocolo baseado nas ações abaixo descritas e representadas pela Figura 7:

- Planejar a pesquisa-ação: iniciar projeto de pesquisa-ação; definir estrutura conceitual-teórica; selecionar unidade de análise e técnica de coleta de dados; definir conceito e propósito;

- Coletar dados: registrar e realimentar dados;

- Analisar dados e planejar ações: tabular dados; comparar dados empíricos com a teoria; elaborar plano de ação;

- Implementar ações: implementar plano de ação desenvolvido; e

- Avaliar resultados e gerar relatórios: avaliar resultados; promover estrutura para replicação; projetar implicações teóricas e práticas; redigir relatório.

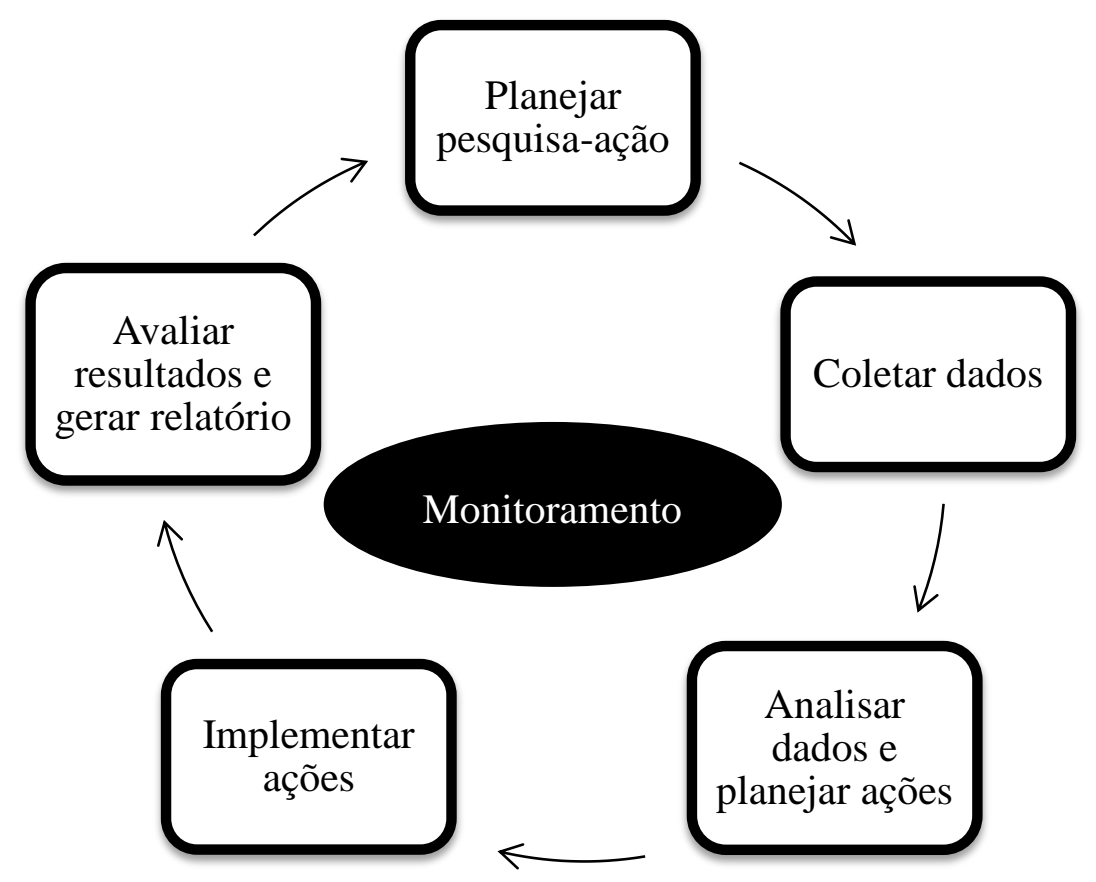

Figura 7: Estrutura para condução da pesquisa-ação FONTE: Adaptado de COUGHLAN e COUGHLAN, 2002.

Nesta dissertação, a pesquisa-ação se concretizou por meio de uma pesquisa participativa; com a implementação de um Escritório de Gerenciamento de Projetos, como uma proposta de solução de um problema, cujos resultados puderam ser verificados e analisados durante a execução do Mestrado Profissional. 
Os próximos subitens desenvolverão de maneira mais detalhada o protocolo proposto, correlacionando a metodologia em questão com o planejamento de trabalho utilizado no desenvolvimento da presente dissertação.

\subsubsection{Planejamento e estrutura da pesquisa-ação}

Coughlan e Coughlan (2002) indicam que a etapa de planejamento da pesquisa-ação deve focar na definição de conceito e propósito, em que se define o tema, diagnostica-se a situação-problema e se indica os principais interessados na pesquisa-ação; na definição da estrutura conceitual-teórica, em que se mapeia a literatura sobre o tema e se determina qual a questão e objetivos de pesquisa; na seleção da unidade de análise e, por fim, nas técnicas de coletas de dados.

Para a pesquisa-ação ora apresentada, as definições necessárias para o protocolo de pesquisa estão sumarizadas na Tabela 5.

Tabela 5: Planejamento da pesquisa-ação (contexto da empresa estudada)

\begin{tabular}{|c|c|c|}
\hline \multirow[t]{3}{*}{ Conceito e propósito } & Tema & Gerenciamento de Projetos \\
\hline & $\begin{array}{l}\text { Diagnóstico e } \\
\text { situação-problema }\end{array}$ & $\begin{array}{l}\text { Má execução dos projetos } \\
\text { estratégicos, impedindo a } \\
\text { implantação da estratégia } \\
\text { organizacional }\end{array}$ \\
\hline & Principais interessados & $\begin{array}{l}\text { Alta Administração } \\
\text { pesquisadora participante }\end{array}$ \\
\hline $\begin{array}{l}\text { Estrutura } \\
\text { conceitual-teórica }\end{array}$ & $\begin{array}{l}\text { Principais autores } \\
\text { (literatura) }\end{array}$ & $\begin{array}{l}\text { Maximiano e Anselmo } \\
\text { (2006), PMI (2013), Reyck et } \\
\text { al. (2005), Dinsmore (2003), } \\
\text { Crawford (2002) }\end{array}$ \\
\hline & Objetivos & $\begin{array}{l}\text { Implantação de um Escritório } \\
\text { de Gerenciamento de } \\
\text { Projetos, comparando a teoria } \\
\text { e a prática }\end{array}$ \\
\hline Unidade de análise & \multicolumn{2}{|c|}{ Empresa de educação definida no item 1.1.1 } \\
\hline $\begin{array}{l}\text { Técnica de coleta de } \\
\text { dados }\end{array}$ & \multicolumn{2}{|l|}{$\begin{array}{l}\text { Registro em arquivos } \\
\text { Entrevistas direcionadas } \\
\text { Observação participante }\end{array}$} \\
\hline
\end{tabular}

FONTE: Elaborado pela autora. 
O diagnóstico e a situação-problema serão apresentados de maneira detalhada no item 4.1 do capítulo seguinte, assim como a literatura foi apresentada de forma integral no Capítulo 2 (Fundamentação Teórica).

\subsubsection{Coleta de Dados}

De acordo com Yin (2010), são seis as fontes de evidências mais comumente utilizadas em projetos de pesquisas: documentação, registro em arquivos, entrevistas, observações diretas, observação participante e artefatos físicos. Estas fontes devem ser analisadas sob a ótica de três princípios: uso de múltiplas evidências e triangulação dos resultados, criação de uma base comprobatória de dados e manutenção do encadeamento das evidências.

As duas principais fontes de coleta de dados nesta pesquisa-ação foram: observação participante e entrevistas direcionadas.

\subsubsection{Observação participante}

Thiollent (2007) define que no caso da pesquisa-ação a geração dos dados vem por meio do envolvimento ativo no projeto e no dia a dia organizacional. Os dados passam, assim, a ser gerados a partir da resolução de problemas cotidianos, das decisões que são tomadas durante a evolução do projeto (como por exemplo a Figura 3, apresentada na Fundamentação Teórica) e das intervenções informais.

No caso da presente dissertação, a pesquisadora teve papel ativo na implantação do Escritório de Gerenciamento de Projetos, sendo uma das maiores protagonistas das ações propostas. Todos os registros foram documentados por meio de apresentações e relatórios, conforme figuras apresentadas ao longo da dissertação e na seção Apêndices. 


\subsubsection{Entrevistas direcionadas}

Belei et al. (2008) indicam que, embora não seja obrigatório, o uso de entrevistas em pesquisas qualitativas é bastante requisitado, necessitando de planejamento prévio e manutenção dos componentes éticos nas suas escolhas (participantes, entrevistador, local, formato e momento de sua realização).

De acordo com Manzini (2004), existem três tipos de entrevistas:

- Estruturada, que contém perguntas fechadas, com pouca flexibilidade, assemelhando-se a questionários quantitativos e formulários com opções préestabelecidas;

- Semiestruturada, que contém perguntas abertas, direcionadas por um roteiro previamente elaborado; $\mathrm{e}$

- Não-estruturada, parte de uma ampla liberdade de formulação com possibilidade de intervenção na fala do entrevistado.

Nesta dissertação, optou-se por entrevistas em profundidade realizadas por meio de um roteiro semiestruturado, conforme apresentado no Apêndice 02. Estas entrevistas foram realizadas com executivos da Alta Administração da empresa durante a implantação do EGP e após dois anos de sua existência.

As principais descobertas, em decorrência das entrevistas, estão detalhadas nos Capítulos $4 \mathrm{e}$ 5 e corroboram para a resposta da questão de pesquisa. Estas descobertas foram decorrentes de análises de conteúdo, com base na metodologia proposta por Bardin (2006). O Apêndice 03 apresenta a estrutura na qual as entrevistas foram analisadas.

\subsubsection{Analisar dados e planejar ações}

Considerando que um dos objetivos da pesquisa-ação é resolver um problema técnico, a análise dos dados coletados deve resultar na elaboração de um plano de ação ou plano de 
intervenção, que deve conter todas as recomendações para a resolução do problema, indicando ações, responsáveis e prazos (Coughlan e Coughlan, 2002).

Ainda de acordo com os autores, as seguintes questões-chave deveriam ser respondidas: o que precisa mudar? em que partes da organização? que tipos de mudanças são necessárias? que tipo de apoio é necessário? como é o compromisso a ser formado? qual a resistência a ser gerenciada?

Biancolino et al. (2012, p. 301) ressaltam que as intervenções podem acontecer de distintas maneiras: consultoria (desenvolvimento de atividades que visam apresentar soluções de problemas), assessoria (trabalho de acompanhamento e avaliação de um processo ou método existente), força tarefa (desenvolvimento de um projeto de intervenção), parecer técnico (diagnóstico de uma situação-problema) e plano (plano de ação para intervenção).

Os mecanismos adotados para a empresa em questão foram força tarefa e implementação de um plano de ação para intervenção. O item 4.2, no capítulo subsequente, descreve as quatro ações propostas, assim como seus principais resultados no momento de sua aplicação.

\subsubsection{Implementar ações}

Nesta etapa "Implentar ações", Coughlan e Coughlan (2002) e Thiollent (2007) indicam que a ação corresponde ao que precisa ser transformado para a solução do problema diagnosticado, sendo uma tarefa que envolve realizar as mudanças desejadas e seguir com os planos de forma colaborativa com os membros-chaves da organização.

No subitem 4.2 (conforme representado na Tabela 6) é possível encontrar a descrição de cada ação e a avaliação de seus resultados, com o detalhamento de fatores críticos e fatores de sucesso para cada uma delas. 
Tabela 6: Esqueleto para análise das ações implementadas

\begin{tabular}{|l|c|}
\hline Ação & Descrição e Resultado da ação \\
\hline Mapeamento dos projetos & item 4.2 .1 \\
\hline $\begin{array}{l}\text { Criação de um escritório de gerenciamento } \\
\text { de projetos e estruturação dos projetos } \\
\text { estratégicos }\end{array}$ & item 4.2 .2 \\
\hline $\begin{array}{l}\text { Sensibilização dos líderes de projeto e } \\
\text { disseminação de uma cultura projetizada }\end{array}$ & item 4.2 .3 \\
\hline $\begin{array}{l}\text { Acompanhamento dos projetos estratégicos } \\
\text { e institucionalização do EGP }\end{array}$ & item 4.2 .4 \\
\hline
\end{tabular}

FONTE: Elaborado pela autora.

\subsubsection{Avaliar resultados e gerar relatório}

A avaliação, de acordo com Coughlan e Coughlan (2002), envolve uma reflexão sobre os resultados da ação, revisando, assim, os processos para o próximo ciclo de pesquisas. Os autores sugerem que os resultados sejam sintetizados em um relatório de pesquisa. Para isso, é de extrema importância que estes resultados estejam estritamente correlacionados com a teoria. Nesta dissertação, o principal resultado foi a implantação de um EGP, que, posteriormente, foi avaliado pelo prisma de seus benefícios e fatores limitantes.

A Tabela 7 sumariza as etapas e resultados obtidos, em consonância com o protocolo sugerido por Coughlan e Coughlan (2002), correlacionando-o com os capítulos da presente dissertação. 
Tabela 7: Sumário da pesquisa-ação e resultados obtidos

\begin{tabular}{|c|c|c|}
\hline Etapas & Técnicas & $\begin{array}{l}\text { Resultados Obtidos } \\
\text { (capítulos da dissertação) }\end{array}$ \\
\hline $\begin{array}{l}\text { Planejar a } \\
\text { pesquisa-ação }\end{array}$ & $\begin{array}{l}\text { Documentação exata } \\
\text { Registro em arquivos } \\
\text { Entrevistas direcionadas } \\
\text { Pesquisa bibliográfica }\end{array}$ & $\begin{array}{l}\text { Capítulo 1: Relato da Experiência (unidade de } \\
\text { análise) } \\
\text { Capítulo 2: Fundamentação Teórica } \\
\text { Capítulo 4: Diagnóstico e situação-problema }\end{array}$ \\
\hline $\begin{array}{l}\text { Coletar } \\
\text { dados }\end{array}$ & $\begin{array}{l}\text { Documentação exata } \\
\text { Registro em arquivos } \\
\text { Entrevistas direcionadas }\end{array}$ & $\begin{array}{l}\text { Capítulo 1: Relato da Experiência (unidade de } \\
\text { análise) } \\
\text { Capítulo 4: Diagnóstico e situação-problema } \\
\text { Capítulo 5: Resultados e Análises (resultados } \\
\text { das entrevistas) } \\
\text { Apêndice 02: Roteiro e protocolo de pesquisa }\end{array}$ \\
\hline $\begin{array}{l}\text { Analisar } \\
\text { dados e } \\
\text { planejar } \\
\text { ações }\end{array}$ & $\begin{array}{l}\text { Pesquisa bibliográfica } \\
\text { Triangulação de dados }\end{array}$ & $\begin{array}{l}\text { Capítulo 2: Fundamentação Teórica } \\
\text { Capítulo 4: Planejamento das ações e detalhes } \\
\text { da intervenção } \\
\text { Capítulo 5: Resultados e Análises }\end{array}$ \\
\hline $\begin{array}{l}\text { Implementar } \\
\text { ações }\end{array}$ & $\begin{array}{l}\text { Implementação } \\
\text { ações das baseado no } \\
\text { protocolo da } \\
\text { pesquisa-ação }\end{array}$ & $\begin{array}{l}\text { Capítulo 4: Planejamento das ações e detalhes } \\
\text { da intervenção }\end{array}$ \\
\hline $\begin{array}{l}\text { Avaliar } \\
\text { resultados e } \\
\text { gerar } \\
\text { relatórios }\end{array}$ & $\begin{array}{l}\text { Pesquisa bibliográfica } \\
\text { Triangulação de dados } \\
\text { Entrevistas direcionadas }\end{array}$ & $\begin{array}{l}\text { Capítulo 4: Principais resultados decorrentes } \\
\text { da proposta de intervenção } \\
\text { Capítulo 4: Relatório técnico decorrente da } \\
\text { intervenção } \\
\text { Capítulo 5: Resultados e Análises }\end{array}$ \\
\hline
\end{tabular}

FONTE: Elaborado a partir de COUGHLAN e COUGHLAN, 2002.

\subsection{Modelo conceitual}

O modelo conceitual de uma dissertação tem por objetivo primário mostrar a forma de estruturação da pesquisa e a relação entre suas principais variáveis. As variáveis desta pesquisa são três: implantação de um EGP, o EGP e os benefícios empresariais decorrentes desta implantação.

A Figura 8 ilustra o modelo conceitual da pesquisa e o relaciona com as etapas apresentadas no Relato da Experiência (1.1): 


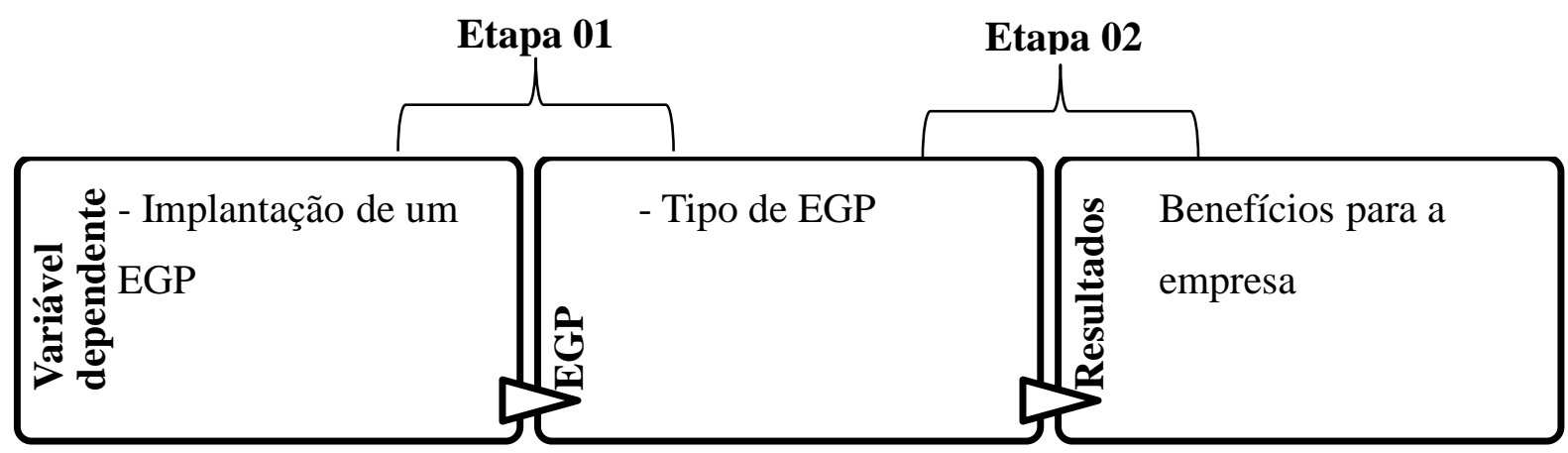

Figura 8: Modelo conceitual da pesquisa FONTE: Elaborado pela autora.

Na Etapa 01, o objetivo conceitual foi a implantação de um EGP, a partir de uma problemática observada e dos benefícios esperados, apresentados pela teoria, de uma gestão estratégica com foco no gerenciamento de projetos. A partir de então, foram evidenciados, na prática, os fatores de sucesso e fatores limitantes desta ação.

A implantação, que ocorreu a partir de um plano de intervenção, deu origem a um EGP, estruturado a partir de um escritório de suporte de projetos, o que definiu seu papel e responsabilidades na organização.

Na Etapa 02, por sua vez, avaliou-se este EGP trazendo como principal resultado os seus benefícios, os fatores de sucesso da implantação e a evolução da atuação do EGP após dois anos.

Este modelo conceitual será um guia para o acompanhamento dos próximos capítulos que têm por objeto detalhar as Etapas 01 e 02 do desenvolvimento da pesquisa-ação. 



\section{INTERVENÇÃO E MECANISMOS ADOTADOS}

As seções seguintes irão explicitar os principais resultados da pesquisa-ação por meio da descrição do diagnóstico e da situação-problema da empresa (4.1), do planejamento das ações e detalhamento da intervenção proposta (4.2) e, por fim, da apresentação dos principais resultados decorrentes desta intervenção (4.3). Estas seções têm por objeto primário apresentar os resultados da Etapa 01 da pesquisa, indicada no Modelo Conceitual.

Este capítulo também corrobora com o objetivo do Mestrado Profissional na medida em que relata uma experiência profissional prática em gerenciamento de projetos, por meio do devido rigor científico, buscando contribuir tecnicamente para a pesquisa acadêmica (BIANCOLINO et al., 2012). Por este motivo, a seção 4.4 apresentará o relato técnico decorrente da intervenção proposta.

\subsection{Diagnóstico e situação-problema}

Conforme o Relato de Experiência previamente apresentado, a empresa estudada (a unidade de análise expressa na Tabela 2) passou a ser gerida por um novo arranjo societário e necessitava de ações urgentes que impulsionassem a entrega de seus projetos estratégicos.

De acordo com o protocolo proposto no subitem 3.3, a situação-problema foi identificada a partir de entrevistas direcionadas aos novos sócios da companhia, conforme roteiro apresentado no Apêndice $02^{10}$.

A coleta de dados mostrou que os seguintes fatores históricos dificultavam o andamento dos projetos na organização:

\footnotetext{
${ }^{10} \mathrm{O}$ Apêndice 03 mostra a estrutura utilizada para a análise de conteúdo das entrevistas. O resultado foi utilizado para a elaboração e construção do presente subitem.
} 
- Dificuldade de entrega (prazo, custo e qualidade desejada) dos projetos definidos como estratégicos pela Alta Administração da empresa;

- Falta de uma cultura corporativa voltada para projetos;

- Baixa sinergia entre os projetos e seus líderes;

- Baixo comprometimento dos líderes de projetos com a entrega;

- Falta de patrocínio e controle da Alta Administração sobre os projetos estratégicos; e

- Alto número de projetos em andamento na empresa.

Estes dados resultaram em um diagnóstico que indicou que a implantação de um EGP seria a melhor solução para minimizar os padrões históricos de má execução de projetos e para cumprir, de maneira eficiente, o novo plano estratégico proposto para a empresa.

O diagnóstico foi apresentado à Alta Administração da empresa por meio de uma apresentação técnica que continha o resumo da situação-problema e indicava como solução a implantação de um Escritório de Gerenciamento de Projetos nível 02, conforme apresentado na Figura 3.

\subsection{Planejamento das ações e detalhamento da intervenção}

A partir da observação participativa da pesquisadora e do aval da Alta Administração, a equipe destinada para a implantação ${ }^{11}$ projetou um plano de intervenção cujo objetivo era garantir que o Escritório de Gerenciamento de Projetos fosse implementado, de acordo com os preceitos teóricos.

Nesse plano foram propostas quatro ações em consonância com a teoria previamente estudada, conforme apresentado na Tabela 8.

\footnotetext{
${ }^{11}$ Equipe formada pela pesquisadora e Diretor Estratégico da empresa estudada.
} 
Tabela 8: Ações propostas no plano de intervenção e literatura estudada

Ação proposta no plano de intervenção

(i) mapear todos os projetos da organização (4.2.1)

\section{Literatura estudada}

Reyck et al., 2005; Rabechini Jr., Maximiano e Martins, 2005; Crawford, 2002; Ghasemzadeh e Archer, 1999; Ghasemzadeh e Archer, 2000 e Copper, 1998

(ii) criar um escritório de gerenciamento de projetos e estruturar os projetos estratégicos escolhidos para fazer parte do EGP (4.2.2)

(iii) sensibilizar os líderes de projeto e disseminar uma cultura projetizada na organização (4.2.3)

(iv) acompanhar os projetos estratégicos, institucionalizando o EGP (4.2.4)
Maximiano e Anselmo, 2006; PMI, 2013; Copper, 1998; Bridges e Crawford, 2002; Martins, Moura e Mesquita, 2011 e Dinsmore, 2003

Martins et al., 2005; Patanakul e Milosevic, 2009 e Dinsmore, 2003

FONTE: Elaborado pela autora a partir da Fundamentação Teórica.

Essas ações, executadas ao longo de seis meses, deram origem ao Escritório de Gerenciamento de Projetos. A descrição das atividades e das ações realizadas, assim como seus principais resultados, estão detalhadas, por ação, a seguir.

\subsubsection{Mapeamento dos projetos}

Todos os projetos em andamento na organização foram mapeados e priorizados, com base nos artigos de Dinsmore (2003), que mostra a importância da correlação dos projetos vigentes com a estratégia corporativa. Para isso, utilizou-se, como ferramenta, uma matriz que considerava a complexidade do projeto em relação a sua relevância estratégica e, então, definiu-se os projetos que seriam cruciais para a implementação da estratégia da empresa (chamados, a partir daí, de projetos estratégicos).

Os projetos estratégicos eram aqueles com maior relevância estratégica e maior complexidade de implantação, seguidos por aqueles com baixa complexidade de implantação e alta relevância estratégica, conforme Figura 9. 


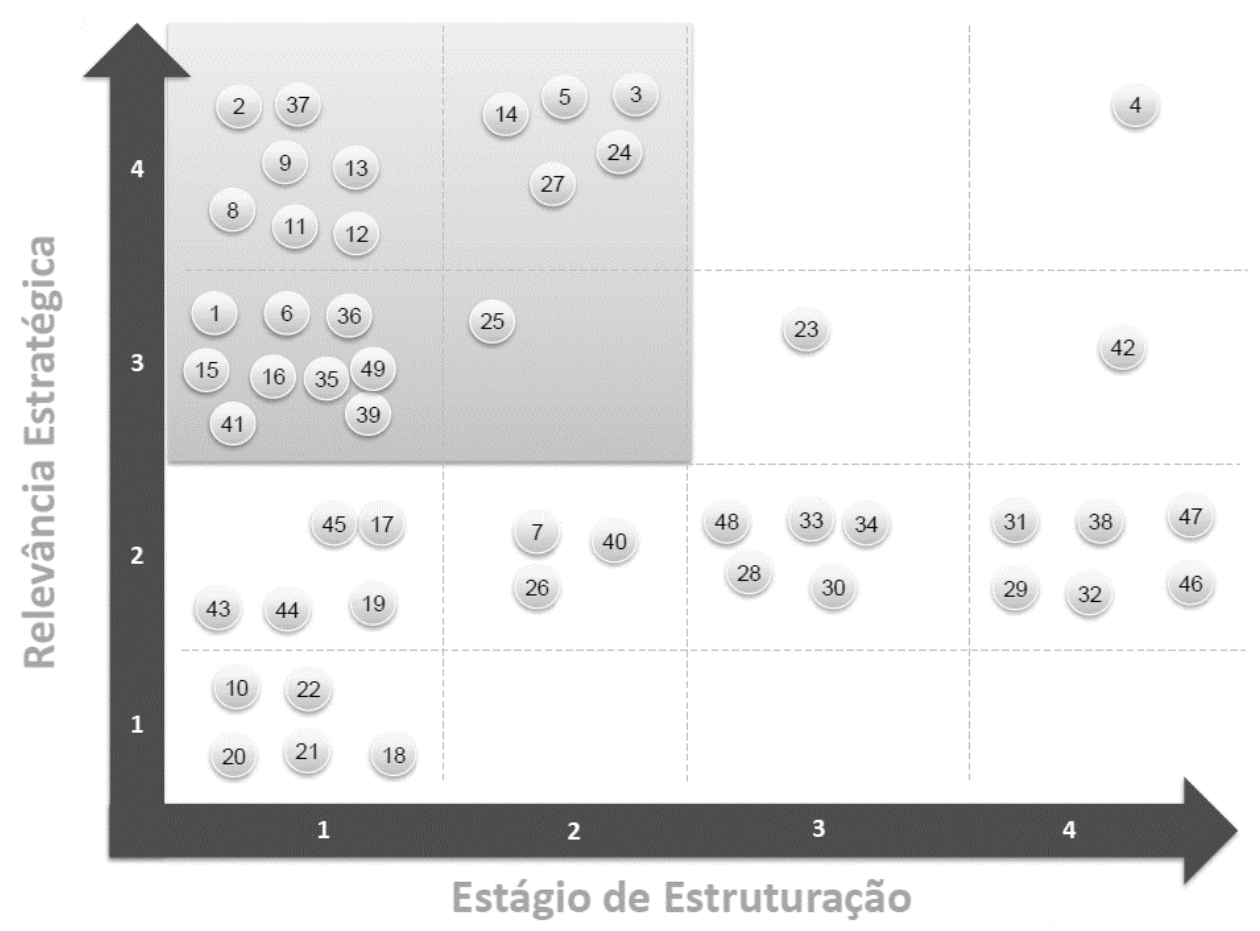

Figura 9: Matriz de relevância estratégica dos projetos em estruturação

FONTE: Elaborado pela autora e apresentado em apresentações técnicas à Alta Administração

\section{$\underline{\text { Resultado da acão: }}$}

Foram priorizados e considerados responsabilidade do EGP 36 projetos dos 49 em destaque na organização. Eles foram divididos em três grupos distintos ${ }^{12}$, conforme quadrantes da Figura 9:

- Projetos de alta relevância estratégica e baixo grau de estruturação;

- Projetos de alta relevância estratégica e alto grau de estruturação; e

- Projetos de baixa relevância estratégica e alto grau de estruturação.

A fim de garantir o engajamento dos responsáveis pela execução, estes 36 projetos foram designados como metas dos principais executivos da empresa, com entregáveis relevantes em seis meses (quando ocorreria a apuração do bônus anual). Estas iniciativas foram distribuídas pelos executivos a seus reportes diretos, nomeados pelo EGP como Líderes de Projetos.

\footnotetext{
12 Os projetos de baixa relevância estratégica e baixo grau de estruturação foram considerados irrelevantes para a estratégia organizacional e não foram mais executados pelos seus líderes.
} 


\subsubsection{Criação de um escritório de gerenciamento de projetos e estruturação dos projetos estratégicos}

O EGP foi criado e nomeado internamente como Oficina de Projetos. A equipe destinada para a implantação apresentou a iniciativa para a Alta Administração como uma área responsável por (i) estruturar os projetos estratégicos da Organização e, posteriormente, (ii) acompanhar seu andamento, por meio de uma postura proativa visando o apoio à entrega. De acordo com a teoria estudada, no subitem 2.4 - PMI (2013) -, apresentou-se um EGP nível 2 (Escritório de Suporte de Projetos).

\section{$\underline{\text { Resultado da acão: }}$}

O EGP foi criado e sua primeira entrega foi a estruturação das 36 iniciativas estratégicas por meio de uma ferramenta simples (planilha Excel). Esta planilha, ilustrada na Figura 10, continha os grandes marcos de entrega dos projetos, as principais atividades necessárias para atingir os marcos, os entregáveis esperados e os prazos acordados.

Foi apresentada à Alta Administração da empresa uma "ficha de projeto" com os principais detalhes de cada um dos projetos, conforme itens abaixo:

- Nome do Projeto: codinome do projeto na empresa;

- Sponsor $^{13}$ : vice-presidente ou diretor responsável pela área;

- Líder do Projeto: responsável direto pelo projeto;

- Consultor da Oficina de Projetos: pessoa do EGP responsável pelo acompanhamento e estruturação do projeto;

- Investimento necessário: valor de investimento ou custos relacionados à implantação do projeto;

- Ganho esperado ou Ebitda ${ }^{14}$ : ganho qualitativo ou quantitativo (representado pelo incremento no Ebitda) para a empresa decorrente da implantação do projeto;

\footnotetext{
${ }^{13}$ Patrocinador, responsável, padrinho.

${ }^{14}$ Indicador financeiro, também chamado de Lajida; representa quanto uma empresa gera de recursos através de suas atividades operacionais, sem contar impostos e outros efeitos financeiros.
} 
- Objetivo: descrição dos principais objetivos do projeto;

- Pontos Críticos: descrição dos principais entraves para a implantação do projeto;

- Grandes marcos: ações a serem executadas (representadas por um verbo) e suas datas de entregas; e

- Entregáveis: entregáveis a serem verificados na finalização dos grandes marcos.

A figura 10 exemplifica uma ficha de projeto (no caso, a estruturação de um modelo de acompanhamento de performance). A planilha em Excel também continha informações detalhadas de cada um dos grandes marcos (um exemplo desta planilha pode ser verificado no Apêndice 04).

Ficha de Projeto

\begin{tabular}{|c|c|c|c|}
\hline Projeto: & \multicolumn{3}{|l|}{ Gestão de performance } \\
\hline Sponsor: & \multicolumn{3}{|l|}{ Responsável 01} \\
\hline Líder: & \multicolumn{3}{|l|}{ Responsável 02} \\
\hline Investimento Necessário: & \multicolumn{3}{|c|}{ R\$ $50 \mathrm{mil} /$ mês, correspondente ao salário dos responsáveis pela área } \\
\hline Ganho Esperado / Ebitda: & \multicolumn{3}{|c|}{ Garantia de atingimento de metas } \\
\hline \multicolumn{2}{|l|}{ Pontos Críticos } & \multicolumn{2}{|l|}{ Objetivo } \\
\hline \multicolumn{2}{|c|}{ Dificuldade em transcrever as metas de maneira quantitati } & \multicolumn{2}{|c|}{$\begin{array}{l}\text { Estruturar um modelo de acompanhamento sistemático da } \\
\text { performance dos executivos garantindo o cumprimento dos } \\
\text { projetos e estratégias definidas }\end{array}$} \\
\hline \multicolumn{2}{|c|}{ Grandes Marcos } & Entregável & Data de Entrega \\
\hline Definir as Metas & & $\begin{array}{c}\text { Planilha com metas de primeiro, segundo } \\
\text { e terceiro nível assinadas. }\end{array}$ & 30 -set-14 \\
\hline Acompanhar as Metas & & Modelo de acompanhamento mensal. & 30 -out-14 \\
\hline Apurar as Metas & & $\begin{array}{l}\text { Atingimento das metas e valor de bônus a } \\
\text { ser pago aos líderes de projetos. }\end{array}$ & $30-a b r-15$ \\
\hline
\end{tabular}

Figura 10: Exemplo de ficha de projeto

FONTE: Elaborado pela equipe de implantação do EGP 
As análises de custos e retorno de grande parte dos projetos ficaram prejudicadas em função do tempo destinado à atividade. Os projetos foram estruturados por dois gerentes em 45 dias e a maior parte dos projetos não possuía informações e dados suficientes para uma análise quantitativa eficiente.

\subsubsection{Sensibilização dos líderes de projeto e disseminação de uma cultura projetizada}

Apesar de o EGP ser institucionalmente apoiado pela Alta Administração, o seu patrocínio não foi relevante nos primeiros meses de funcionamento. Por este motivo, no processo de estruturação dos projetos, houve uma grande resistência dos Líderes de Projeto em relação à dinâmica proposta pela Oficina de Projetos (conforme previamente alertado pela teoria).

Os principais motivos identificados para a resistência dos Líderes dos Projetos foram:

1. Falta de tempo para se dedicar à aplicação de uma metodologia de estruturação de projetos,

2. Não engajamento com o novo processo; e

3. Visão do EGP como uma área de burocratização e cobrança.

Percebeu-se, portanto, a necessidade de um maior engajamento dos líderes e da difusão da cultura projetizada para a organização.

\section{Resultado da ação:}

Agregaram-se, como função do EGP, treinamentos contínuos àqueles envolvidos com os projetos estratégicos. O primeiro treinamento ocorreu no final da fase de estruturação e início da fase de acompanhamento, como forma de sensibilizar os líderes mais resistentes e de proporcionar um conhecimento básico sobre Gerenciamento de Projetos (necessidade de homogeneização dos líderes, que estavam distribuídos em diferentes áreas da empresa, com conhecimentos e habilidades distintas). 
Os conteúdos apresentados neste treinamento foram:

- Definição de projetos, processos e Escritório de Gerenciamento de Projetos (EGP);

- Apresentação de jargões técnicos e principais instituições (PMI, PMBOK e PMP);

- Definição de portfólio de projetos;

- Desenvolvimento de conceitos aplicados ao gerenciamento de projetos: ficha de abertura, escopo (EAP ou WBS), cronograma e caminho crítico, recursos humanos, qualidade, riscos, custos e ferramentas de garantia de qualidade.

Após o treinamento, tanto os Líderes dos Projetos quanto a Alta Administração foram sensibilizados da importância do bom funcionamento do EGP para a execução do plano estratégico da empresa.

Algumas fotos e os melhores momentos do treinamento foram disponibilizados na televisão corporativa e houve uma grande mudança de postura em relação ao recém-implantado Escritório de Gerenciamento de Projetos. Os Líderes de Projetos que, ainda assim, não se identificaram com a nova cultura projetizada foram substituídos com o aval da Alta Administração.

\subsubsection{Acompanhamento dos projetos estratégicos e institucionalização do EGP}

O acompanhamento pelo EGP foi projetado para ser executado de forma proativa, atuando em conjunto com os Líderes de Projeto e focando a rápida implantação dos projetos, a qualidade dos entregáveis, o alinhamento dos projetos com a visão estratégica da Alta Administração e o cumprimento do cronograma de entregas previamente acordado.

Para garantir a eficácia do acompanhamento, foram programadas reuniões mensais de apuração dos principais resultados com a presença do presidente da empresa. Ter o presidente presente foi de suma importância para a formalização do EGP, uma vez que seu patrocínio garantia e ratificava a forma de atuação dos responsáveis pela Oficina de Projetos. 


\section{$\underline{\text { Resultado da ação: }}$}

Como institucionalização processual, o EGP gerava relatórios semanais com insights (informações relevantes percebidas no dia a dia dos projetos que, em muitos casos, não eram relatadas nos acompanhamentos formais) para garantir que todos os pontos relevantes fossem tratados na presença do presidente ou dos executivos responsáveis.

\subsection{Principais resultados decorrentes da proposta de intervenção}

O principal resultado do plano de intervenção foi a criação e institucionalização do Escritório de Gerenciamento de Projetos na organização. Considerando que no subitem anterior foi detalhado o passo a passo desta implantação, este subitem tem como principal objetivo resumir as características do EGP.

Serão detalhados os seguintes aspectos: organograma, estrutura de cargos, papéis e responsabilidades, e custos.

\section{Organograma:}

O EGP ficou ligado à Diretoria Estratégica da empresa estudada, conforme representado na Figura 11.

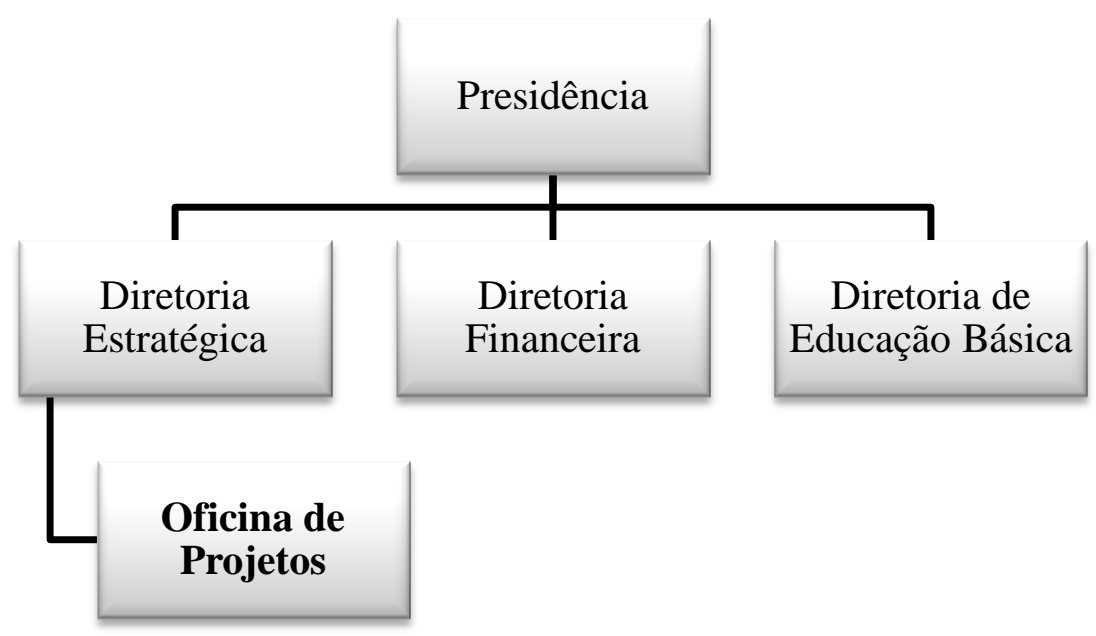

Figura 11: Organograma pós-implantação do EGP FONTE: Elaborado pela autora. 


\section{Estrutura de Cargos:}

Apesar de a estruturação dos projetos ter sido executada por dois gerentes, percebeu-se que, para o dia a dia da Oficina de Projetos, era necessário apenas um recurso sênior da organização. Por esta razão, a estrutura de cargos foi redefinida, conforme Figura 12.

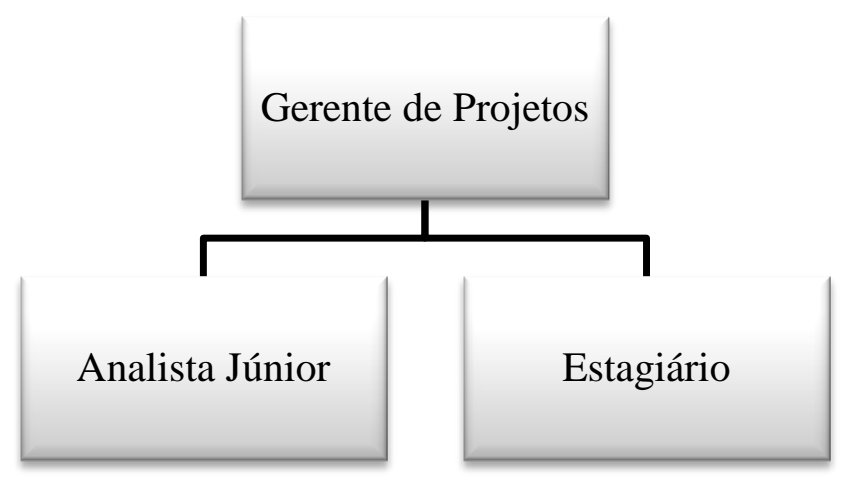

Figura 12: Estrutura de cargos do EGP FONTE: Elaborado pela autora.

\section{Papéis e Responsabilidades:}

Considerando os tipos de EGP apresentados na fundamentação teórica, os principais papéis e responsabilidades de um Escritório de Gerenciamento de Projetos foram listados na Tabela 9, conforme PMI (2013).

A tabela apresenta as funções assinaladas com um $\mathrm{X}$ em relação às responsabilidades da Oficina de Projetos (ou EGP), dos Líderes dos Projetos e da Presidência da empresa. 
Tabela 9: Papéis e responsabilidades da Oficina de Projetos

\begin{tabular}{|c|c|c|c|}
\hline $\begin{array}{c}\text { Papéis e } \\
\text { Responsabilidades }\end{array}$ & $\begin{array}{c}\text { Oficina de } \\
\text { Projetos }\end{array}$ & $\begin{array}{l}\text { Líderes dos } \\
\text { Projetos }\end{array}$ & Presidência \\
\hline $\begin{array}{lcr}\text { Elaborar } & \text { relatório } & \text { de } \\
\text { progresso e desempenho } & \end{array}$ & $\mathbf{X}$ & & \\
\hline Monitorar resultados & $\mathbf{X}$ & & \\
\hline $\begin{array}{l}\text { Manter base de dados } \\
\text { histórica e lições aprendidas }\end{array}$ & $\mathbf{X}$ & & \\
\hline $\begin{array}{l}\text { Fornecer treinamento em } \\
\text { gerenciamento de projetos }\end{array}$ & $\mathbf{X}$ & & \\
\hline $\begin{array}{l}\text { Estabelecer } \\
\text { cumprimento de } \\
\text { métricas }\end{array}$ & $\mathbf{X}$ & & \\
\hline $\begin{array}{l}\text { Possibilitar alinhamento dos } \\
\text { projetos às estratégias do } \\
\text { departamento }\end{array}$ & $\mathbf{X}$ & & \\
\hline $\begin{array}{lrr}\text { Definir, implementar } & \text { e } \\
\text { controlar mecanismos } & \text { de } \\
\text { controle de mudanças } & \end{array}$ & & $\mathbf{X}$ & \\
\hline $\begin{array}{l}\text { Assumir o papel de mentor } \\
\text { para projetos com } \\
\text { problemas }\end{array}$ & $\mathbf{X}$ & & \\
\hline $\begin{array}{l}\text { Padronizar o gerenciamento } \\
\text { dos projetos }\end{array}$ & $\mathbf{X}$ & & \\
\hline $\begin{array}{ll}\text { Identificar, priorizar } & \mathrm{e} \\
\text { selecionar os projetos } & \end{array}$ & & & $\mathbf{X}$ \\
\hline $\begin{array}{lcc}\text { Gerenciar os } & \text { recursos } \\
\text { corporativamente } & \end{array}$ & & & $\mathbf{X}$ \\
\hline $\begin{array}{l}\text { Implantar e manter um } \\
\text { sistema de informações }\end{array}$ & & $\mathbf{X}$ & \\
\hline $\begin{array}{l}\text { Alinhar os projetos às } \\
\text { estratégias corporativas }\end{array}$ & & & $\mathbf{X}$ \\
\hline $\begin{array}{l}\text { Promover desenvolvimento } \\
\text { profissional dos membros } \\
\text { do EGP }\end{array}$ & $\mathbf{X}$ & & \\
\hline
\end{tabular}

FONTE: Elaborado a partir de PMI, 2013.

\section{Custos:}

Os custos relacionados à implantação do EGP estavam associados aos salários das pessoas por ele responsáveis. Uma vez institucionalizado, percebeu-se que apenas um recurso sênior poderia ser responsável pelo acompanhamento dos projetos. Foi proposta, portanto, uma redução de custos para o nível de $\mathrm{R} \$ 500$ mil anual (considerando o organograma previamente apresentado). 


\subsection{Relatório técnico decorrente da intervenção}

Ainda como parte do processo de pesquisa-ação, gerou-se um relatório técnico apresentando os principais resultados da pesquisa, traçando-se um paralelo entre os resultados obtidos a partir da implantação e a teoria previamente estudada. A tabela-resumo (Tabela 10) a seguir tem por objetivo sumarizar estes resultados, corroborando, também, para os objetivos de um Mestrado Profissional.

A alta aderência entre prática e teoria ocorreu porque durante o processo de pesquisa-ação muitos dos questionamentos e dificuldades encontrados na prática foram solucionados à luz da teoria.

Os pontos de atenção levantados consistentemente pela teoria, como necessidade de patrocínio da Alta Administração, possibilidade de resistência interna, importância de definição do escopo do EGP e importância da apresentação dos ganhos futuros, foram sistematicamente verificados na prática. Buscou-se, desta forma, aplicar as soluções propostas pela literatura. 
Tabela 10: Resumo do relatório técnico

\begin{tabular}{|c|c|c|c|}
\hline Prática & $\begin{array}{c}\text { Ponto relevante da } \\
\text { Teoria }\end{array}$ & $\begin{array}{l}\text { Observações } \\
\text { Empíricas }\end{array}$ & $\begin{array}{l}\text { Aderência entre } \\
\text { Prática e Teoria }\end{array}$ \\
\hline $\begin{array}{l}\text { Mapeamento dos } \\
\text { projetos. }\end{array}$ & $\begin{array}{l}\text { Importância de uma } \\
\text { seleção criteriosa, } \\
\text { principalmente no } \\
\text { caso de multi- } \\
\text { projetos. }\end{array}$ & $\begin{array}{l}\text { Seleção } r \text { de } \\
\text { projetos rápida e } \\
\text { com poucos } \\
\text { critérios objetivos. }\end{array}$ & $\begin{array}{l}\text { Baixa } \\
\text { Projetos mal } \\
\text { selecionados geraram } \\
\text { retrabalho para o EGP. }\end{array}$ \\
\hline $\begin{array}{lr}\text { Criação de } & \text { um } \\
\text { Escritório } & \text { de } \\
\text { Gerenciamento } & \text { de } \\
\text { Projetos } & \text { e } \\
\text { Estruturação } & \text { dos } \\
\text { Projetos } & \\
\text { Estratégicos. } & \end{array}$ & $\begin{array}{l}\text { Implementação de } \\
\text { um EGP a partir de } \\
\text { suas funções e de } \\
\text { um passo a passo } \\
\text { definido. }\end{array}$ & $\begin{array}{l}\text { Implementação de } \\
\text { um EGP nível } 2 \text { e } \\
\text { constatação do } \\
\text { processo de } \\
\text { resistência interna. }\end{array}$ & $\begin{array}{l}\text { Alta } \\
\text { Prática estruturada a } \\
\text { partir da teoria. Os } \\
\text { pontos de atenção } \\
\text { ressaltados pela teoria } \\
\text { foram de } \\
\text { importância suma } \\
\text { direcionar para } \\
\text { implantação. }\end{array}$ \\
\hline $\begin{array}{l}\text { Sensibilização dos } \\
\text { Líderes de Projeto e } \\
\text { Disseminação de } \\
\text { uma Cultura } \\
\text { Projetizada. }\end{array}$ & $\begin{array}{lr}\text { Importância } & \text { da } \\
\text { cultura voltada para } \\
\text { o comprometimen- } \\
\text { to, a comunicação, } \\
\text { o trabalho em } \\
\text { equipe e a } \\
\text { recompensa por } \\
\text { resultado. }\end{array}$ & $\begin{array}{lr}\text { Cultura } & \\
\text { empresarial } & \text { pouco } \\
\text { voltada } & \text { para } \\
\text { recompensa } & \text { por } \\
\text { resultado } & \text { de } \\
\text { projetos. } & \end{array}$ & $\begin{array}{l}\text { Alta } \\
\text { A falta de cultura } \\
\text { projetizada mostrou-se } \\
\text { um limitador para a } \\
\text { implantação do EGP. } \\
\text { Portanto, muitos Líderes } \\
\text { de Projetos foram } \\
\text { substituídos. }\end{array}$ \\
\hline $\begin{array}{l}\text { Acompanhamento } \\
\text { dos projetos } \\
\text { estratégicos e } \\
\text { institucionalização } \\
\text { do } \\
\text { EGP. }\end{array}$ & $\begin{array}{l}\text { Importância do } \\
\text { patrocínio da Alta } \\
\text { Administração. }\end{array}$ & $\begin{array}{l}\text { Acompanhamento } \\
\text { dos projetos com } \\
\text { o patrocínio da } \\
\text { Alta Administra- } \\
\text { ção permitiu a } \\
\text { institucionalização } \\
\text { do EGP na } \\
\text { Organização. }\end{array}$ & $\begin{array}{l}\text { Alta } \\
\text { O patrocínio da Alta } \\
\text { Administração, permitiu } \\
\text { que o acompanhamento } \\
\text { se tornasse um processo } \\
\text { contínuo da Organiza- } \\
\text { ção. }\end{array}$ \\
\hline
\end{tabular}

FONTE: Elaborado pela autora.

O único ponto que apresentou baixa aderência entre teoria e prática durante a implantação do EGP foi a seleção dos projetos estratégicos (posteriormente identificado como um fator limitador pela Alta Administração). Apesar de a teoria recorrentemente apontar para a importância de uma seleção criteriosa da carteira de projetos, com base em ferramentas específicas, conforme Apêndice 01, este ponto não conseguiu ser implantado na prática durante a pesquisa-ação. 
Isso ocorreu, principalmente, pela falta de consenso na priorização dos projetos pela Alta Administração e pela quantificação falha que foi feita em um período curto de tempo.

\subsubsection{Seleção e priorização dos projetos}

As etapas de mapeamento e estruturação dos projetos não se mostraram eficientes na prática, uma vez que muitos deles foram reavaliados pela Alta Administração, que também demonstrou dificuldade na definição dos projetos prioritários.

Após a implantação do EGP, vinte projetos foram revisitados e retirados da Oficina de Projetos, mostrando que a seleção inicial não estava devidamente correlacionada com os objetivos estratégicos da organização.

Isso ocorreu, pois grande parte dos projetos já estava em andamento na organização (portanto, eles foram apenas organizados a partir da lógica apresentada no subitem 4.2.1) e não foram selecionados pelos novos sócios, recém-adquirentes da empresa.

O EGP, nos meses posteriores, teve retrabalho na adequação da carteira de projetos à estratégia vigente da companhia. 


\section{RESULTADOS E ANÁLISES}

O capítulo anterior apresentou o passo a passo para a implantação do EGP, seus principais resultados e a correlação encontrada entre a teoria e a prática durante o momento de pesquisa. Esta foi a Etapa 01 da pesquisa, conforme inicialmente apresentado no Relato da Experiência e no Modelo Conceitual.

A Etapa 02, por sua vez, tem como objetivo primordial apresentar os resultados do Escritório de Gerenciamento de Projetos sob a perspectiva da Alta Administração da empresa, após dois anos de sua implantação, listando os benefícios e fatores limitantes da atuação do EGP.

Para isso, foram feitas entrevistas em profundidade, com base no questionário apresentado no Apêndice 02 desta dissertação. Os resultados das entrevistas estão descritos nos subitens a seguir.

\subsection{Verificação dos benefícios e fatores limitantes}

Foram entrevistados executivos da empresa para compreender, a partir de suas percepções, quais os benefícios e fatores limitantes do EGP, contemplando também os fatores de sucesso e os principais custos imbuídos em sua implantação. Os resultados das entrevistas estão sumarizados na tabela abaixo e foram elaborados a partir da análise de conteúdo proposta no Apêndice 03. 
Tabela 11: Resultado das Entrevistas

\begin{tabular}{|c|c|c|c|}
\hline Benefícios & Fatores Limitantes & Fatores de Sucesso & Custos \\
\hline $\begin{array}{l}\text { Alinhamento dos } \\
\text { projetos com a } \\
\text { estratégia da empresa }\end{array}$ & $\begin{array}{l}\text { Resistência dos } \\
\text { líderes dos projetos }\end{array}$ & $\begin{array}{l}\text { Apoio da Alta } \\
\text { Administração }\end{array}$ & Time \\
\hline Gestão de prioridade & Mudança de cultural & $\begin{array}{l}\text { Clareza na estruturação } \\
\text { dos projetos e seus } \\
\text { entregáveis }\end{array}$ & $\begin{array}{l}\text { Consultorias } \\
\text { externas }\end{array}$ \\
\hline $\begin{array}{l}\text { Visibilidade pela Alta } \\
\text { Administração }\end{array}$ & $\begin{array}{l}\text { Consenso na } \\
\text { priorização dos } \\
\text { projetos }\end{array}$ & $\begin{array}{l}\text { Profundidade e } \\
\text { entendimento dos } \\
\text { projetos }\end{array}$ & \\
\hline $\begin{array}{l}\text { Organização dos } \\
\text { projetos }\end{array}$ & $\begin{array}{l}\text { Quantificação do } \\
\text { benefício dos } \\
\text { projetos }\end{array}$ & $\begin{array}{l}\text { Recorrência e } \\
\text { objetividade de } \\
\text { acompanhamento }\end{array}$ & \\
\hline $\begin{array}{l}\text { Mobilização de times } \\
\text { para execução }\end{array}$ & $\begin{array}{l}\text { Disseminação de } \\
\text { práticas de } \\
\text { estruturação }\end{array}$ & $\begin{array}{l}\text { Relacionamento criado } \\
\text { entre líderes de projeto } \\
\text { e EGP }\end{array}$ & \\
\hline \multicolumn{4}{|l|}{ Mitigação de risco } \\
\hline \multicolumn{4}{|l|}{$\begin{array}{l}\text { Priorização e } \\
\text { realocação de recursos }\end{array}$} \\
\hline \multicolumn{4}{|l|}{$\begin{array}{l}\text { Garantia de entrega } \\
\text { (custo e prazo) }\end{array}$} \\
\hline \multicolumn{4}{|l|}{$\begin{array}{l}\text { Responsabilização dos } \\
\text { líderes }\end{array}$} \\
\hline $\begin{array}{l}\text { Padronização de } \\
\text { informações e } \\
\text { acompanhamento }\end{array}$ & & & \\
\hline
\end{tabular}

FONTE: Elaborado pela autora.

Os próximos subitens exporão de maneira mais detalhada informações sobre os benefícios percebidos pela Alta Administração na implantação de um Escritório de Gerenciamento de Projetos (5.1.1), os principais fatores limitantes desta implantação (5.1.2), os seus fatores de sucesso (5.1.3) e, por fim, os custos de implantação (5.1.4).

\subsubsection{Principais benefícios}

Os benefícios da implantação do EGP na empresa, de acordo com a percepção da Alta Administração, foram divididos seguindo as dimensões apresentadas na Tabela 1, provenientes da visão de Anselmo (2009), ou seja, (i) estratégica, (ii) organizacional e (iii) operacional: 


\section{(i) Dimensão estratégica:}

- Clareza na agenda operacional da companhia, a partir do alinhamento dos projetos em andamento com a estratégia vigente;

- Início de uma gestão de prioridades, por meio do acompanhamento de projetos importantes para a estratégia estabelecida; e

- Aumento da visibilidade pela Alta Administração sobre o andamento dos projetos estratégicos.

\section{(ii) Dimensão Organizacional:}

- Organização dos diversos projetos em curso na companhia;

- Mobilização do time para a execução e entrega dos projetos pactuados com a Alta Administração;

- Articulação das áreas envolvidas para a mitigação de riscos e a busca de soluções conjuntas; e

- Ampliação da capacidade de discutir, priorizar e realocar recursos, a partir de necessidades reais de execução.

\section{(iii) Dimensão Operacional:}

- Garantia de entrega dos projetos dentro do custo e nos prazos estimados;

- Maior responsabilização dos Líderes dos Projetos pelo sucesso ou fracasso de seus projetos;

- Padronização de informações; e

- Maior facilidade de diálogo entre as áreas envolvidas pelos projetos.

Os benefícios percebidos pela Alta Administração estão em total consonância, tanto com a prática inicialmente relatada no Capítulo 4, como com a teoria estudada no Capítulo 2.

O EGP trouxe para a empresa benefícios estratégicos, organizacionais e gerenciais de grande relevância para a evolução da companhia, desde sua estratégia até sua execução por meio de projetos. Estes benefícios evidenciam também a evolução da empresa em seu modelo de gestão, conforme apresentado nas Considerações Finais e Conclusões. 


\subsubsection{Fatores limitantes}

A visão da Alta Administração em relação aos fatores limitantes, ou críticos, da implantação foram sumarizadas nos quatro itens que se seguem:

- Resistência dos líderes dos projetos e mudança cultural.

Os líderes dos projetos não acreditavam que haveria uma verdadeira parceria com os representantes do EGP. Além disso, não possuíam a cultura de estruturação e acompanhamento de projetos, destinando pouco tempo de seu dia a dia para os rituais estabelecidos.

- Consenso na priorização dos projetos pela Alta Administração.

A definição do que era um projeto relevante para a organização foi um fator crítico durante a implantação do EGP.

- Quantificação do benefício de cada projeto.

Muitos projetos foram quantificados apenas qualitativamente, aumentando a dificuldade do processo de priorização acima citado.

- Disseminação de práticas de estruturação e de acompanhamento para os demais níveis da empresa.

Associando os fatores limitantes citados pelos executivos, dois anos após a implantação, com o resultado do plano de intervenção apresentado no Capítulo 4, nota-se uma grande consonância do processo de implantação.

A resistência dos Líderes dos Projetos e a dificuldade de mudança cultural foram rapidamente percebidas e, por meio de um plano de ação (detalhado no subitem 4.2.3), foram mitigadas. É válido ressaltar que a falta de patrocínio por alguns membros Alta Administração não foi identificada por nenhum dos executivos, porém ocorreu na prática. A mitigação da resistência dos Líderes de Projeto aconteceu justamente no momento em que os próprios executivos foram sensibilizados e entenderam os benefícios da implantação do EGP. 
Adicionalmente, a implantação do EGP foi prejudicada, principalmente, na etapa de seleção de projetos, seja pela falta de consenso na priorização dos projetos pela Alta Administração ou pela quantificação falha de seus benefícios, conforme apresentado no item 4.3.1 e evidenciado no Relatório Técnico decorrente da implantação. A seleção de projetos foi o item com menor aderência entre prática e teoria estudada.

A disseminação de boas práticas não foi um ponto inicialmente verificado na Etapa 01 da pesquisa-ação, porém foi um fator limitante, conforme trazido pela visão de um dos executivos da organização, uma vez que fazia parte do escopo do EGP nível 02 e não apresentou nenhum resultado relevante neste sentido.

\subsubsection{Fatores de sucesso}

Os fatores de sucesso da implantação do EGP, de acordo com os executivos entrevistados, foram:

- Apoio da Alta Administração, principalmente do presidente da empresa;

- Clareza na estruturação dos projetos e seus entregáveis;

- Profundidade e entendimento, em detalhes, de todos os projetos em acompanhamento;

- Recorrência e objetividade do acompanhamento (papéis e rotinas bem definidas); e

- Relacionamento criado entre líderes de projeto e EGP (envolvimento, cumplicidade e responsabilidade mútua pelas entregas). O EGP tinha como objetivo agregar valor aos projetos e não apenas efetuar o acompanhamento de cronogramas.

Durante o processo de implantação do EGP, os fatores de sucesso, citados pelos executivos, foram previamente estudados e, por esta razão, foram implementados na prática, conforme Relatório Técnico decorrente da intervenção.

Apesar de não citado por nenhum dos executivos, a interação entre teoria e prática promovida pelo Mestrado Profissional foi vital para o sucesso do EGP. 


\subsubsection{Custos}

Os principais custos citados pelos executivos foram relacionados a pessoas (time responsável pela Oficina de Projetos) e eventuais consultorias, como, por exemplo, capacitações sobre o tema gerenciamento de projetos, caso do treinamento citado no item 4.2.3.

A implantação do EGP, nos moldes propostos, mostrou-se uma ação relativamente barata em comparação aos benefícios trazidos para a empresa, uma vez que o tema custos não foi apontado por nenhum executivo como ponto de preocupação.

\subsection{A atuação do EGP após dois anos}

Após dois anos da implantação do EGP, percebeu-se uma significativa mudança na cultura da empresa em questão e, consequentemente, em sua estratégia e modelo de gestão, conforme evidenciado nas entrevistas com os executivos da empresa.

Em um primeiro momento, de estruturação da empresa e consolidação da nova liderança, o modelo de EGP inicialmente proposto trouxe benefícios, disciplina e rigor de acompanhamento dos projetos. Todavia, com a evolução do modelo de gestão da empresa, o acompanhamento dos projetos passou a acontecer de forma descentralizada.

Atualmente, os projetos estratégicos fazem parte da gestão de cada diretoria, não sendo mais necessário um acompanhamento corporativo que garanta as entregas de cada projeto. De acordo com PMI (2013), esta estrutura pode ser chamada de EGP de Unidade Organizacional, EGP de Unidade de Negócio, EGP de Divisão ou EGP de Departamento.

A Alta Administração apontou que o EGP foi de extrema importância para o contexto inicialmente estudado, uma vez que introduziu metodologias de gerenciamento de projetos e comprovou os benefícios que a estruturação e o acompanhamento de projetos trazem para a estratégia e resultados da empresa. 
A partir do aprendizado da experiência prática em consonância com a teoria, grandes projetos na empresa ainda se beneficiam de um EGP específico, conforme pontuado por PMI (2013) EGP de Projeto Específico, Escritório de Projeto, Escritório de Programa. Projetos estruturantes (como, por exemplo, a integração de um novo ativo adquirido) possuem um Escritório de Projeto Específico e exclusivo para acompanhamento de suas entregas.

Os cinco maiores projetos da companhia são recorrentemente acompanhados pela Presidência, em contraposição aos 36 inicialmente apontados como responsabilidade do EGP. Isso comprova que a priorização dos projetos e a definição do que é realmente relevante para a estratégia empresarial evoluiu de maneira significativa.

\subsubsection{Comparação dos principais resultados iniciais}

O EGP previamente implantado, por sua vez, evoluiu para uma área que passou a ser chamada de Gerenciamento e Gestão, cujo principal objetivo é garantir o acompanhamento das metas e pactos trimestrais da empresa.

As principais adequações feitas no modelo inicial do EGP, com base na evolução de gestão da empresa, serão detalhadas a partir dos aspectos previamente apresentados no item 4.3: organograma, estrutura de cargos, papéis e responsabilidades, e custos.

\section{Organograma:}

O EGP deixou de ser denominado Oficina de Projetos e foi intitulado como área de Gerenciamento e Gestão. Também, como resultado da adequação, passou a ter reporte direto à Presidência da empresa, conforme Figura 13. 


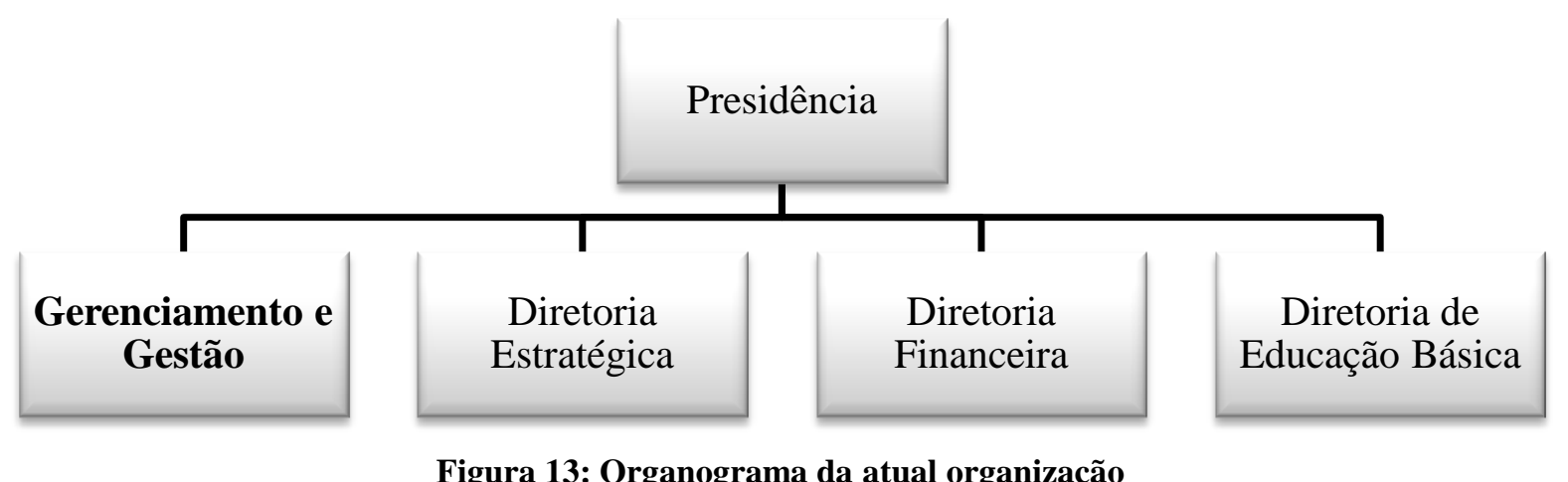

Figura 13: Organograma da atual organização FONTE: Elaborado pela autora.

O reporte direto à Presidência é de extrema relevância, tanto teórica como prática, uma vez que corrobora com a necessidade do alto patrocínio para as áreas relacionadas com gestão e gerenciamento. Conforme os resultados das entrevistas, este foi um dos fatores de sucesso da implantação do EGP, que foi mantido nas adequações propostas.

\section{Estrutura de Cargos:}

A estrutura de cargos foi ampliada, uma vez que o processo de gestão passou a ter maior relevância estratégica na empresa. Houve também mudança de pessoas nos cargos em decorrência de promoções e movimentações internas.

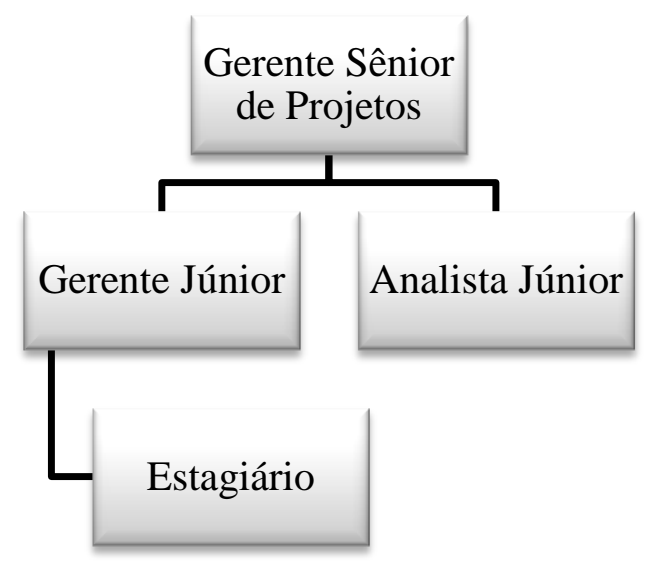

Figura 14: Estrutura de cargos da área de Gerenciamento e Gestão FONTE: Elaborado pela autora 


\section{Papéis e Responsabilidades:}

Os papéis e responsabilidades da área foram essencialmente mantidos, porém, uma vez que houve uma transição do modelo de gestão da companhia, modificações importantes ocorreram em quatro aspectos: (i) assunção do papel de mentor para projetos com problemas, (ii) priorização e seleção dos projetos, (iii) alinhamento dos projetos às estratégias corporativas e (iv) promoção do desenvolvimento profissional dos membros do EGP, conforme tabela abaixo.

Tabela 12: Papéis e responsabilidades da área de Gerenciamento e Gestão

\begin{tabular}{|c|c|c|c|}
\hline Papéis e Responsabilidades & $\begin{array}{c}\text { Área de } \\
\text { Gerenciamento } \\
\text { e Gestão }\end{array}$ & $\begin{array}{c}\text { Líderes dos } \\
\text { Projetos }\end{array}$ & Presidência \\
\hline $\begin{array}{l}\text { Elaborar relatório de progresso e } \\
\text { desempenho }\end{array}$ & $\mathbf{X}$ & & \\
\hline Monitorar resultados & $\mathbf{X}$ & & \\
\hline $\begin{array}{l}\text { Manter base de dados histórica e } \\
\text { lições aprendidas }\end{array}$ & $\mathbf{X}$ & & \\
\hline $\begin{array}{lll}\begin{array}{l}\text { Fornecer } \\
\text { gerenciamento de projetos }\end{array} & \text { em } \\
\end{array}$ & $\mathbf{X}$ & & \\
\hline \begin{tabular}{lrr} 
Estabelecer & e & \multicolumn{2}{c}{ verificar } \\
cumprimento & de & padrões e \\
métricas & &
\end{tabular} & $\mathbf{X}$ & & \\
\hline $\begin{array}{lrr}\text { Possibilitar } & \text { alinhamento } & \text { dos } \\
\text { projetos às } & \text { estratégias } & \text { do } \\
\text { departamento } & & \end{array}$ & $\mathbf{X}$ & & \\
\hline $\begin{array}{l}\text { Definir, implementar e controlar } \\
\text { mecanismos de controle de } \\
\text { mudanças }\end{array}$ & & $\mathbf{X}$ & \\
\hline $\begin{array}{l}\text { Assumir o papel de mentor } \\
\text { para projetos com problemas }\end{array}$ & & $\mathbf{X}$ & \\
\hline $\begin{array}{l}\text { Padronizar o gerenciamento dos } \\
\text { projetos }\end{array}$ & $\mathbf{X}$ & & \\
\hline $\begin{array}{l}\text { Identificar, priorizar } \\
\text { selecionar os projetos }\end{array}$ & $\mathbf{X}$ & & $\mathbf{X}$ \\
\hline $\begin{array}{lll}\text { Gerenciar os recursos } \\
\text { corporativamente }\end{array}$ & & & $\mathbf{X}$ \\
\hline $\begin{array}{l}\text { Implantar e manter um sistema } \\
\text { de informações }\end{array}$ & & $\mathbf{X}$ & \\
\hline $\begin{array}{l}\text { Alinhar os projetos às } \\
\text { estratégias corporativas }\end{array}$ & $\mathbf{X}$ & & $\mathbf{X}$ \\
\hline $\begin{array}{l}\text { Promover desenvolvimento } \\
\text { profissional dos membros do } \\
\text { EGP }\end{array}$ & n.a & n.a & n.a \\
\hline
\end{tabular}

FONTE: Elaborado pela autora. 
Considerando o novo contexto da área, uma mudança de papel relevante foi a assunção do papel de mentoria (i), em relação a projetos com problemas, por parte dos Líderes de Projetos e executivos responsáveis pelas respectivas áreas - corroborando com a visão de descentralização trazida pelos executivos.

Esta função, inicialmente dada ao EGP, foi repassada aos responsáveis pela execução dos projetos estratégicos. Isso ocorreu tendo em vista que os principais responsáveis pelos projetos são aqueles mais indicados para analisar riscos e viabilizar soluções propositivas, já que estão envolvidos no dia a dia operacional dos projetos.

Outra mudança de papel se deu em relação à priorização e seleção dos projetos (ii). A seleção de projetos passou a fazer parte do escopo da área de Gerenciamento e Gestão, junto à Presidência da empresa. Esta adequação está em plena consonância com os preceitos teóricos, com o gap $^{15}$ de implantação do EGP, previamente identificado no item 4.3.1, e com os resultados das entrevistas, que considerou este um fator crítico de implantação.

No início da implantação do EGP, os projetos já estavam sendo executados e muitos deles foram revisitados com o passar dos meses. Neste novo modelo, todos os novos projetos passam pelo crivo e análises da área de Gerenciamento e Gestão, sendo ponderados quantitativamente e qualitativamente com o auxílio da visão estratégica da Presidência da empresa. Desta forma, garante-se que novas demandas, incoerentes com a estratégia vigente, não interrompam a execução dos projetos estratégicos em andamento.

Em consonância com a mudança de papel da área em relação à seleção de projetos, o alinhamento dos projetos às estratégias corporativas (iii) também passou a ser escopo da área de Gerenciamento e Gestão, gerando, desta maneira, uma maior coerência entre estratégia e projetos.

\footnotetext{
${ }^{15}$ Termo em inglês que significa um distanciamento; afastamento, separação, uma lacuna ou um vácuo.
} 
Por fim, a promoção do desenvolvimento profissional dos membros do EGP (iv) deixou de ser uma prioridade da empresa, uma vez que as novas contratações para a área de Gerenciamento e Gestão já foram feitas a partir da definição de um perfil específico de gerente e analista.

\section{Custos:}

Conforme resultados das entrevistas, a estrutura de pessoas representou a maior parte dos custos da área. Portanto, analisando os itens Estrutura de Cargos e Custos de maneira conjunta, pode-se dizer que os custos foram mantidos coerentes com a estrutura de cargos, não apresentando nenhum grande diferencial estratégico.

\subsubsection{Confronto entre teoria e prática}

Os benefícios citados pela teoria no subitem 2.5 foram comparados com a percepção dos executivos sobre a implantação do EGP na Tabela 13. A tabela mostra, a partir das observações empíricas, que as adequações no modelo do EGP (funções e responsabilidades) foram essenciais para que os benefícios trazidos pela teoria fossem averiguados e vivenciados na prática da empresa ora estudada. 
Tabela 13: Comparação entre teoria e prática em relação aos benefícios de um EGP

\section{Teoria descrita no item 2.5 , com base em Cooper, Edgett e Kleinschmit, 1998 e PMI, 2013}

Criação de uma base comum para a discussão, busca por disciplina e consistência no gerenciamento dos projetos.

Estabelecimento de foco e concentração em grandes projetos e projetos inovadores.

\section{Identificado na prática pelos executivos?}

\section{Observações empíricas}

Sim Ocorreu de acordo com o previsto.

As etapas de mapeamento e estruturação dos projetos não se mostraram eficientes na prática, uma vez que muitos deles Não foram reavaliados pela Alta Administração, que também demonstrou dificuldade na definição dos projetos prioritários.
Busca por uma melhor adequação estratégica, correlacionando coerentemente estratégia e carteira

Não de projetos.

Vinte projetos foram revisitados e retirados da Oficina de Projetos, mostrando que a seleção inicial não estava devidamente correlacionada com os objetivos estratégicos da organização.

Auxílio no equilíbrio entre os projetos de curto e longo prazo

Sim

Ocorreu de acordo com o previsto, após adequação supracitada (5.2.1).

Foco e concentração nos poucos projetos que mais valem à estratégia da organização,

Sim

Ocorreu de acordo com o previsto, após adequação supracitada (5.2.1).

\begin{tabular}{|c|c|c|}
\hline $\begin{array}{l}\text { Auxílio no go-to-market de } \\
\text { maneira mais aprimorada. }\end{array}$ & Sim & $\begin{array}{l}\text { Ocorreu de acordo com o previsto, } \\
\text { após adequação supracitada }(5.2 .1) \text {. }\end{array}$ \\
\hline $\begin{array}{l}\text { Unificação de suportes e níveis } \\
\text { estratégicos da empresa. }\end{array}$ & Sim & $\begin{array}{l}\text { A função inicialmente dada ao EGP foi } \\
\text { repassada aos responsáveis pela } \\
\text { execução dos projetos estratégicos. Isso } \\
\text { ocorreu uma vez que os principais } \\
\text { responsáveis pelos projetos são aqueles } \\
\text { mais indicados para analisar riscos e } \\
\text { viabilizar soluções propositivas, visto } \\
\text { que estão envolvidos no dia a dia } \\
\text { operacional dos projetos. Criou-se EGP } \\
\text { de Projeto Específico para projetos de } \\
\text { grande porte. }\end{array}$ \\
\hline $\begin{array}{l}\text { Melhoria no processo de } \\
\text { acompanhando do planejamento } \\
\text { estratégico. }\end{array}$ & Sim & $\begin{array}{l}\text { O EGP previamente implantado evoluiu } \\
\text { para uma área que passou a ser chamada } \\
\text { de Gerenciamento e Gestão, cujo } \\
\text { principal objetivo é garantir o } \\
\text { acompanhamento das metas e pactos } \\
\text { trimestrais da empresa. }\end{array}$ \\
\hline
\end{tabular}

FONTE: Elaborado a partir de COOPER, EDGETT e KLEINSCHMIT, 1998. 
Grande parte dos benefícios apontados por Cooper, Edgett e Kleinschmit (1998) foram identificados na prática pela Alta Administração, exceto por dois tópicos: (i) estabelecimento de foco e concentração em grandes projetos e projetos inovadores e (ii) busca por uma melhor adequação estratégica, correlacionando coerentemente estratégia e carteira de projetos.

Conforme apresentado no subitem 4.4.1 (seleção e priorização dos projetos), a seleção dos projetos não se mostrou eficiente na prática da empresa estudada. Os projetos selecionados para serem acompanhados pelo EGP não necessariamente representavam os grandes projetos ou aqueles mais inovadores. Esta etapa gerou retrabalho e, posteriormente, passou a ser analisada de forma estruturada na organização: todos os novos projetos, antes de serem executados ou acompanhados, deveriam passar por um crivo qualitativo e quantitativo e deveriam ser anuídos pelo Presidente da empresa.

Outro benefício indicado por Cooper, Edgett e Kleinschmit (1998) e Dinsmore (2003) - a busca por uma melhor adequação estratégica, correlacionando coerentemente estratégia e carteira de projetos - também não foi averiguado no momento da implantação do EGP, justamente em decorrência da má seleção dos projetos.

Para os demais tópicos apresentados na tabela 13, entende-se que a nova estrutura hierárquica-organizacional (descrita no subitem 5.2.1), conforme proposição de Bridges e Crawford (2002), foi de suma importância para que os benefícios teóricos fossem reconhecidos na prática empresarial pela Alta Administração. 



\section{CONSIDERAÇÕES FINAIS E CONCLUSÃO}

O objetivo central desta pesquisa foi implantar, por meio de uma pesquisa-ação, um EGP na empresa estudada e verificar os principais benefícios gerados para a execução de sua estratégia, assim como os fatores limitantes de sua implantação. A questão de pesquisa percorrida foi: quais são os benefícios e fatores limitantes da implantação de um Escritório de Gerenciamento de Projetos para a empresa em questão?

Os benefícios desta implantação foram significativos para a empresa nas dimensões estratégica, organizacional e operacional - resultando em uma mudança de cultura e gestão da empresa. Os principais benefícios listados pela Alta Administração, dois anos após a implantação do EGP, foram:

- Clareza na agenda operacional da companhia a partir do alinhamento dos projetos em andamento com a estratégia vigente;

- Gestão de prioridades, acompanhamento de projetos importantes para a estratégia estabelecida;

- Visibilidade para a Alta Administração sobre o andamento dos projetos estratégicos;

- Organização dos diversos projetos em curso na companhia;

- Mobilização do time para execução e entrega dos projetos pactuados com a Alta Administração;

- Articulação das áreas envolvidas para mitigação de riscos e busca de soluções conjuntas;

- Ampliação da capacidade de discutir, priorizar e realocar recursos a partir de necessidades reais de execução;

- Garantia de entrega dos projetos dentro do custo e prazo estimados;

- Maior responsabilização dos líderes dos projetos pelo seu sucesso ou fracasso; e

- Padronização de informações e maior facilidade de diálogo entre as áreas.

Os fatores limitantes, por sua vez, foram identificados tanto no momento da implantação do EGP, quanto verificados pela Alta Administração, posteriormente. São eles: 
- Resistências relacionadas a uma nova cultura projetizada (principal mote da implantação de um EGP);

- Dificuldade de consenso da Alta Administração em relação à seleção dos projetos estratégicos;

- Dificuldade na quantificação dos benefícios dos projetos selecionados; e

- Falta de disseminação de boas práticas para todos os níveis gerenciais.

Em relação aos fatores limitantes, é válido voltar a atenção para o tema seleção de projetos, uma vez que este foi o maior fator limitante, aparecendo com recorrência na pesquisa realizada. As principais formas de seleção de multi-projetos estratégicos na prática contrapuseram-se às teorias descritas na literatura.

Apesar de a literatura elencar indicadores para a seleção de projetos, conforme Apêndice 01, a prática indicou que o consenso entre a Alta Administração nem sempre é atingido, gerando problemas na concepção dos projetos, portfólios e estratégias que podem ser maléficos para a execução da estratégia. De acordo com Vargas (2010), o processo cognitivo dos executivos acaba influenciando a tomada de decisão racional.

Os objetivos secundários, indicados no item 1.3, também foram alcançados, sendo eles: o mapeamento do passo a passo da implantação de um EGP (comparando teoria e prática), a identificação de fatores de sucesso e custos de implantação e a descrição da evolução do EGP na estrutura organizacional.

O passo a passo da implantação do EGP foi mapeado e apresentado no Capítulo 4, por meio do detalhamento da intervenção decorrente do plano de ações. Como resultado desta intervenção, apresentou-se a Tabela 10 que compara da teoria e a prática durante o processo de implantação. Este passo a passo pode ser considerado um framework baseado em preceitos teóricos e também testado e aplicado na prática empresarial.

Esta dissertação também contribui para a prática analisando os principais fatores de sucesso na implantação do EGP e seus custos para a empresa estudada. O primeiro deles foi o apoio e patrocínio da Alta Administração, um dos fatores mais relevantes para a institucionalização do EGP na empresa. Além disso, a estruturação dos projetos e seus entregáveis estabelecidos 
de forma clara e profunda foram de extrema relevância durante a implantação, somada ao envolvimento, cumplicidade e parceria entre os líderes dos projetos e os responsáveis pelo EGP. Por fim, a continuidade e eficácia do EGP mostrou-se possível a partir de um acompanhamento dos projetos estabelecido de forma recorrente e objetiva, com reuniões mensais ou semanais, a partir de pautas e responsabilidades bem definidas. Ademais, de acordo com a percepção dos executivos, o framework proposto teve um baixo custo em relação aos benefícios que trouxe para a gestão da empresa.

Por fim, a evolução do EGP em suas tarefas e formato foi apresentada no item 5.2.1. A adequação do modelo de EGP às novas necessidades da empresa foi de suma importância para que a prática empresarial pudesse encontrar os benefícios propostos na teoria. O processo de implantação do EGP deixou aprendizados proeminentes que continuam sendo utilizados no cotidiano organizacional por meio de Escritórios de Gerenciamento de Projetos Específicos.

\subsection{Resumo a partir do modelo conceitual}

O modelo conceitual da pesquisa, ilustrado na Figura 8, buscou compreender a partir da implantação de um EGP quais os principais benefícios gerados para a empresa estudada, unidade de análise da presente dissertação.

Os principais resultados foram sumarizados na Figura 15 que buscou relacionar o modelo conceitual inicial com resultados obtidos. 


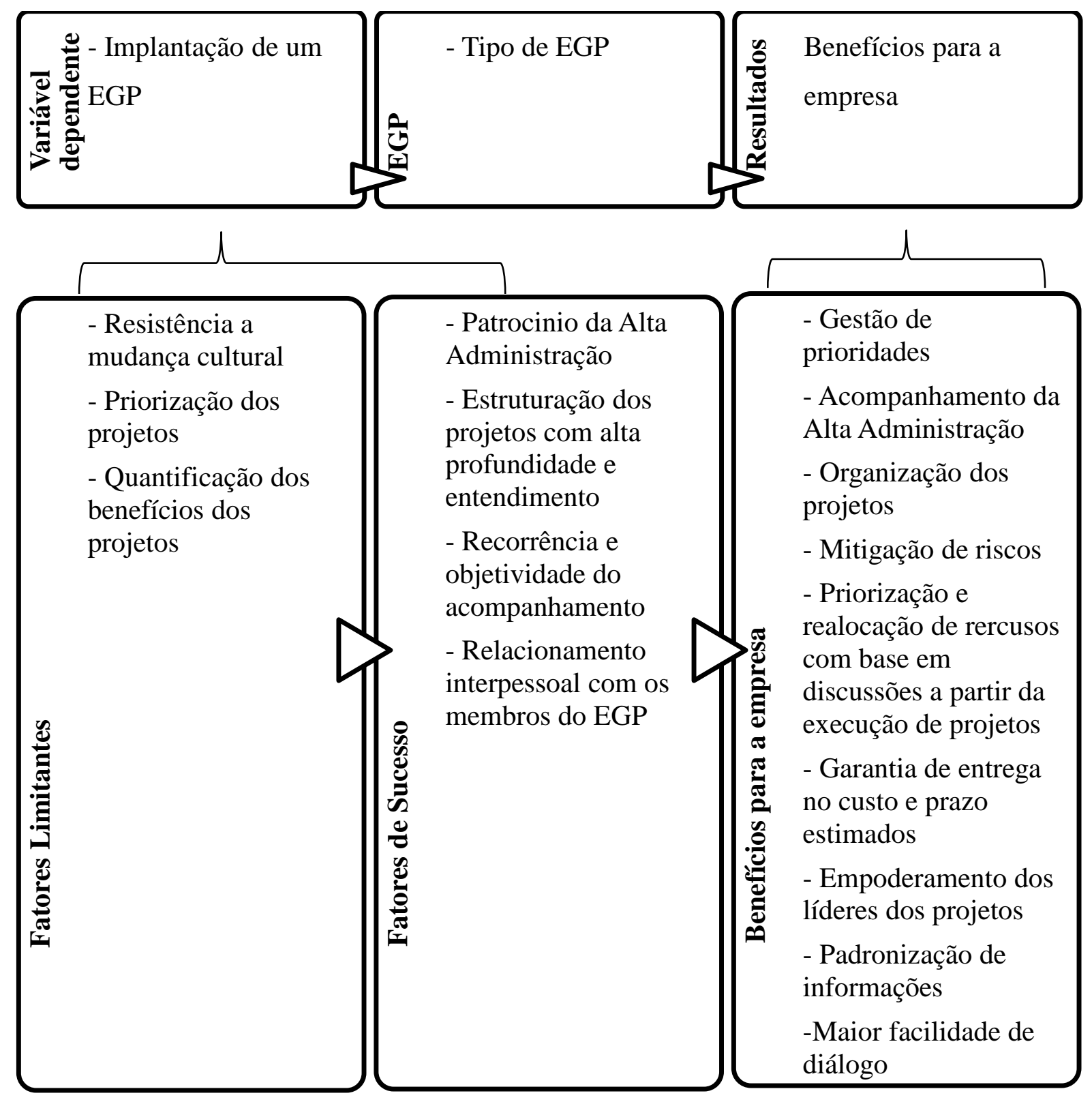

Figura 15: Resumo a partir do modelo conceitual FONTE: Elaborado pela autora.

\subsection{Contribuições para prática e para a academia}

O Mestrado Profissional trouxe um benefício concreto para a prática empresarial, uma vez que a presente dissertação, com base no que foi proposto pela academia, trouxe uma evolução de gestão significativa, em particular, para a empresa estudada. 
Isso ocorreu não apenas pela implantação de um EGP com base nos preceitos teóricos, mas também pela evidenciação da evolução de seu modelo de gestão, ao longo de dois anos de acompanhamento do dia a dia empresarial. Os resultados do plano de intervenção e a consolidação da percepção da Alta Administração trouxeram luz à presente dissertação.

Esta pesquisa é, portanto, um indicativo de que o modelo de gestão da empresa, proposto pelos novos sócios, está em consonância com os objetivos estratégicos traçados inicialmente na aquisição e que evoluiu em busca dos benefícios gerados pelo gerenciamento de projetos.

A dissertação também contribuiu para a consolidação do conceito acadêmico do Mestrado Profissional, uma vez que é resultado da intensa interação entre teoria e prática, conforme apresentado na Figura 1. A pesquisa e a ação ocorreram de forma concomitante resultando em benefícios relevantes tanto para a prática como para a academia.

O método de pesquisa-ação, aplicado dentro dos rigores acadêmicos, mostrou-se confluente com o que é esperado pela academia em um Mestrado Profissional e auxiliou a implantação de um plano de intervenção com foco na resolução de um problema específico.

\subsection{Limitações da pesquisa e sugestões para estudos futuros}

A pesquisa-ação, método da presente dissertação, foi aplicada em uma única empresa com características específicas, tais como: atuação no setor de educação básica, grande porte e controle acionário proveniente de um fundo de investimento. A replicação do passo a passo de implantação do EGP não foi aplicada em outros tipos de empresas e, por conseguinte, os benefícios e fatores limitantes não podem ser generalizados a partir dos resultados e análises desta dissertação.

Outra limitação importante é que os benefícios, percebidos pela Alta Administração, não foram verificados de maneira quantitativa. A análise dos projetos e de seus resultados financeiros poderiam contribuir quantitativamente para as conclusões apresentadas, comprovando que a existência de um EGP gerou benefícios financeiros para a organização. 
Para estudos futuros, portanto, sugere-se a aplicação do framework de implantação de escritórios de gerenciamento de projetos, por meio do método pesquisa-ação, em empresas com características distintas (ramo de atividade, porte e controle acionários), assim como a mensuração de resultados através de KPI financeiros. 


\section{REFERÊNCIAS}

ALBERTON, A. et al. Seleção de investimentos: aspectos e ferramentas relevantes na perspectiva dos gestores. In: Anais do XXIV Encontro Nacional de Engenharia de Produção, Florianópolis: ABEPRO, 2004.

ANSELMO, J. L. Gerenciamento de projetos em negócios baseado em projetos: uma proposta integrada das dimensões operacional, organizacional e estratégica. São Paulo, 2009. Tese (Doutourado em Administração) - Programa de Pós Graduação em Administração, Faculdade de Economia, Administração e Contabilidade da Universidade de São Paulo.

AUBRY, M.; HOBBS, B.; THUILLIER, D. A New Framework for Understanding Organisational Project Management Through the PMO. International Journal of Project Management. East Horsley: Elsevier, v. 25, n. 4, p. 328-336, May 2007.

BARDIN, L. Análise de conteúdo. Trad. L. de A. Rego e A. Pinheiro. Lisboa: Edições 70, 2006.

BELEI, R. A. et al. O uso de entrevista, observação e vídeo gravação em pesquisa qualitativa. Cadernos de educação. Pelotas: FaE/PPGE/UFPel, n. 30, p. 187-199, Jan./Jun. 2008.

BIANCOLINO, C. A. et al. Protocolo para elaboração de relatos de produção técnica. Revista de gestão e projetos. São Paulo, v. 3, n. 2, p. 294-307, Mai./Ago. 2012.

BRIDGES, D. N.; CRAWFORD, J. K. A Project Office - where and what type. Proceedings of the Project Management Institute Annual Seminars \& Symposium. Nashville, Tenn.. 1-10 Nov., 2001.

BOUER, R.; CARVALHO, M. M. Metodologia singular de gestão de projetos: condição suficiente para a maturidade em gestão de projetos. Produção. São Paulo: ABEPRO, v. 15, n. 3, p. 347-361, Set./Dez. 2005.

CRAWFORD, J. K. The Strategic Project Office: a guide to improving organizational performance. New York: Marcel Dekker, 2002.

COOPER, R. G.; EDGETT, S. J.; KLEINSCHMIT, E. J. Portfolio Management for New Products. New York: Perseus Publishing, 1998.

COUGHLAN, P.; COGHLAN, D. Action Research for Operations Management. International Journal of Operations \& Production Management. [S.l.]: Emeral, v. 22, n. 2, p. 220-240, 2002.

DINSMORE, P. C. Transformando estratégias empresariais em resultados através da gerência por projetos. Rio de Janeiro: Qualitymark Ed., 2003. 
ENGLUND, R. L.; GRAHAM, R. J. From Experience: Linking Projects to Strategy. Journal of Product Innovation Management. [S.1.]: Wiley, v. 16, n. 1, p. 52-64, Jan. 1999.

FISCHER, T. Mestrado profissional como prática acadêmica. Revista brasileira de pósgraduação. v. 2, n. 4, p. 24-29, Jul. 2005.

FREITAS, H. et al. O método de pesquisa survey. Revista de administração da Universidade de São Paulo. São Paulo, v. 35, n. 3, p. 105-112, Jul./Set. 2000.

GHASEMZADEH, F.; ARCHER, N. P. An Integrated Framework for Project Portfolio Selection. International Journal of Project Management. East Horsley: Elsevier, v. 17, n. 4, p. 207-216, Aug. 1999.

GHASEMZADEH, F.; ARCHER, N. P. Project Portfolio Selection Through Decision Support. Decision Support Systems. East Horsley: Elsevier, v. 29, n. 1, p. 73-88, Jul. 2000.

GODOY, A. S. Introdução à pesquisa qualitativa e suas possibilidades. Revista de administração de empresas. São Paulo: FGV, v. 35, n. 2, p. 57-63, Mar./Abr. 1995.

GUEDES, R. M. et al. Alinhamento do portfólio de projetos à estratégia das organizações: um estudo exploratório quantitativo. Economia \& Gestão. Belo Horizonte: PUC Minas, v. 11, n. 27, p. 67-93, Set./Dez. 2011.

JOOSTE, C.; FOURIE, B. The Role of Strategic Leadership in Effective Strategy Implementation: Perceptions of South African Strategic Leaders. Southern African Business Review. [S.1.]: Univ. of South Africa, v. 13, n. 3, p. 51-68, 2009.

JUGDEV, K.; MULLER, R. A Restropective Look at our Evolving Understanding of Project Sucess. Project Management Journal. [S.1.]: PMI, v. 36, n. 4, Dez. 2005.

JUGDEV, K.; THOMAS, J. Project Managment Maturity Models: the Silver Bullets of Competitive Advantage? Project Management Journal. [S. 1.]: PMI, v. 33, n. 4, Dez. 2002.

KAPLAN, R. S.; NORTON, D. P. The Strategy-focused Organization. Strategy and Leadership. [S.1.]: Emeral, v. 29, n. 3, p. 41-42, 2001.

KAPLAN, R. S.; NORTON, D. P. Creating the Office of Strategy Management. [S.1.]: Division of Research, Harvard Business School, 2005.

KERZNER, H. Project management: a systems approach to planning, scheduling and controlling. New Jersey: Jonh Wiley \& Sons, Inc., 2003, 8a ed. 
KING, W. R. Project management handbook. New York: Van Nostrand Reinhold, 1993.

MACCARI, E. A. et al. Sistema de avaliação da pós-graduação da Capes: pesquisa-ação em um programa de pós-graduação em Administração. Revista brasileira de pós-graduação. São Paulo, v. 5, n. 9, p. 171-205, 2008.

MANZINI, E. J. Entrevista: definição e classificação. Marília: Unesp, 2004. 4 transparência. $\mathrm{P} \& \mathrm{~B}, 39 \mathrm{~cm} \times 15 \mathrm{~cm}$.

MARTINS, A. P. et al. Implantação e consolidação de escritório de gerenciamento de projetos: um estudo de caso. Produção. São Paulo: ABEPRO, v. 15, n. 3, p. 404-415, Set./Dez. 2005.

MARTINS, H. C.; MOURA, M. T.; MESQUITA J. M. C. Escritório de projetos como resposta estratégica da organização: um estudo de caso na Vale. Revista de gestão e projetos. São Paulo, v. 2, n. 2, p. 26-52, Jul./Dez. 2011.

MAXIMIANO, A. C. A.; ANSELMO, J. L. Escritório de gerenciamento de projetos: um estudo de caso. Revista de administração da Universidade de São Paulo. São Paulo, v. 41, n. 4, p. 394-403, Out./Dez. 2006.

MEADE, L. M.; PRESLEY, A. R\&D Project Selection Using the Analytic Network Process. IEEE Transactions on Engineering Management. [S.1.]: IEEE, v. 49, n. 1, p. 59-66, 2002.

MELLO, C. H. P. et al. Pesquisa-ação na engenharia de produção: proposta de estruturação para sua condução. Produção. São Paulo: ABEPRO, v. 22, n. 1, p. 1-13, Jan./Fev. 2012.

MUSTAFA, M. A.; AL-BAHAR, J. F. Project Risk Assessment Using the Analytic Hierarchy Process. IEEE Transactions on Engineering Management. [S.1]: IEEE, v. 38, n. 1, p. 46$52,1991$.

PATANAKUL, P.; MILOSEVIC, D. The Effectiveness in Managing a Group of Multiple Projects: Factors of Influence and Measurement Criteria. International Journal of Project Management. East Horsley: Elsevier, v. 27, n. 3, p. 216-233, Abr. 2009.

PINSONNEAULT, A. e KRAEMER, K. L. Survey research in management information systems: an assessement. Journal of Management Information System. V. 10, n. 2, p. 75$105,1993$.

PMI, PMI's Pulse of Professions: PMO Frameworks, Newton Square: Project Management Institute, 2013.

PMI, PMI's Pulse of Professions: The Impact of PMOs on Strategy Implementation, Newton Square: Project Management Institute, 2013. 
PORTER, M. E. What is Strategy? Harvard Business Review, v. 74, n. 6, p. 61-78, Nov./Dez. 1996.

RABECHINI JR, R.; MAXIMIANO, A. C. A.; MARTINS, V. A. A adoção de gerenciamento de portfólio como uma alternativa gerencial: o caso de uma empresa prestadora de serviço de interconexão eletrônica. Produção. São Paulo: ABEPRO, v. 15, n. 3, p. 416-433, Set./Dez. 2005.

REYCK, B. D. et al. The Impact of Project Portfolio Management on Information Technology Projects. International Journal of Project Management. East Horsley: Elsevier, v. 23, n. 7, p. 524-537, Out. 2005.

RODRIGUES, I.; RABECHINI JR., R.; CSILLAG, J. M. Os escritórios de projetos como indutores de maturidade em gestão de projetos. Revista de administração da Universidade de São Paulo. São Paulo, v. 41, n. 3, p. 273-287, Jul./Ago./Set. 2006.

RUSSO, R. de F. S. M.; SBRAGIA, R. Tendência empreendedora do gerente: uma análise de sua relevância para o sucesso de projetos inovadores. Gestão \& Produção. São Carlos: Univ. Federal de São Carlos, v. 14, n. 3, p. 581-593, Set./Dez. 2007.

SILVEIRA, V. O. da; PINTO, F. C. de S. Reflexões necessárias sobre o mestrado profissional. Revista brasileira de Pós-Graduação. São Paulo, v. 2, n. 4, p. 38-47, Jul. 2005.

SÖDERLUND, J. Building Theories of Project Management: Past Research, Questions for the Future. International Journal of Project Management. East Horsley: Elsevier, v. 22, n. 3, p. 183-191, Abr. 2004.

THIOLLENT, M. Metodologia da pesquisa-ação. São Paulo: Cortez; 2007.

UNGER, B. N.; GEMÜNDEN, H. G.; AUBRY, M. The Three Roles of a Project Portfolio Management Office: their Impact on Portfolio Management Execution and Success. International Journal of Project Management. East Horsley: Elsevier, v. 30, n. 5, p. 608620, Jul. 2012.

VARGAS, R. V. Utilizando a programação multicritério (Analytic Hierarchy Process-AHP) para selecionar e priorizar projetos na gestão de portfólio. In: Anais do PMI Global Congress 2010. Disponível em: <http://www.leansixsigma.com.br/acervo/2215922.pdf>. Acesso em: 11/04/2015.

YIN, R. K. Estudo de Caso: planejamento e métodos. 4․ ed. Porto Alegre: Bookman, 2010. 


\section{APÊNDICES}

APÊNDICE 01: CRITÉRIOS PARA SELEÇÃO DE PROJETOS APÊNDICE 02: ROTEIRO E PROTOCOLO DE PESQUISA

APÊNDICE 03: ESTRUTURA PARA ANÁLISE DE CONTEÚDO

APÊNDICE 04: EXEMPLO DE PLANILHA EM EXCEL QUE ESTRUTUROU OS PROJETOS ESTRATÉGICOS DA ORGANIZAÇÃO 


\section{APÊNDICE 01: CRITÉRIOS PARA SELEÇÃO DE PROJETOS}

\section{Critérios}

\section{Financeiro}

Avaliação de critérios que buscam captar os benefícios financeiros de um projeto

\section{Estratégico}

Avaliação de critérios relacionados aos objetivos estratégicos da organização e sua correlação com o projeto

\section{Ferramentas}

Retorno do Investimento (ROI): margem $(\%)$ de lucro operacional do projeto.

Lucro Operacional: valor em moeda (\$) do lucro operacional.

Valor Presente Líquido (VPL): diferenças entre entradas e saídas do projeto trazidas à data presente, a partir de uma determinada taxa de juros.

Período de Retorno (Payback): período de tempo para recuperar os investimentos originais do projeto.

\section{Taxa Financeira de}

Custo/Benefício: razão entre o valor presente dos ganhos e o valor presente das despesas.

Taxa Interna de Retorno (TIR): $\%$ de retorno do dinheiro investido ao longo do tempo.

Indicadores Balanceados de Desempenho (Balanced Scorecard): indicadores que mostram o alinhamento das metas com a estratégia organizacional ${ }^{16}$.

\section{Comentários, exemplos e benefícios}

Comparação do ROI de diferentes projetos (projetos com maior ROI podem ser mais interessantes).

- Projetos de maior lucro nominal podem ser escolhidos em detrimento daqueles com maior ROI (valores nominais podem contar mais que $\%$ da margem).

- $\quad$ Possibilidade de avaliação de projetos que tenham fluxos de saída e entradas em diferentes momentos do tempo, trazidos para a mesma base de comparação.

- Possibilidade de cálculo do período de retorno líquido (com fluxos trazidos a valor presente).

- Quanto maior o quociente, mais viável o projeto do ponto de vista custo/benefício.

- Pode ser utilizado

concomitantemente com o critério de VPL e payback.

- Critérios estratégicos,

diferente dos financeiros, são específicos para cada organização.

- Projetos alinhados com o direcionamento estratégico da Organização podem ter prioridade em relação aos demais.

- Exemplos de riscos em Matriz de Risco: matriz projetos: ato de Deus, físicos, analisando os tipos de riscos, seus econômicos, ato do príncipe, político, impactos e relevância. realizar ou não determinado projeto.

\section{Urgência}

Avaliação do nível de urgência para realização de um projeto.

Cronograma: definição de cronogramas e marco relevantes na tomada de decisão. economicos, ato do príncipe, político,
ambientais, risco de imagem, risco de design, entre outros.

\section{- $\quad$ Projetos urgentes requerem} ações e decisões imediatas.

\section{Comprometimento das} partes interessadas

Avaliação do grau de comprometimento das partes interessadas de um projeto.

\section{Conhecimento técnico}

Avaliação do conhecimento técnico necessário para realização de um projeto.
Avaliações qualitativas das partes interessadas

\section{- Comprometimento de}

clientes, comunidade, organização, órgãos reguladores, equipe do projeto, gerente do projeto.

Projetos técnicos
Quanto maior o conhecimento técnico, maior a facilidade e menor custo para realização de um projeto.

FONTE: VARGAS, 2010; MEADE e PRESLEY, 2002; ALBERTON et al., 2004; MUSTAFA e AL-BAHAR, 1991.

\footnotetext{
${ }^{16}$ Conceitos em acordo com Kaplan e Norton, 2005.
} 


\section{APÊNDICE 02: ROTEIRO E PROTOCOLO DE PESQUISA}

Roteiro de perguntas para diagnóstico e situação-problema (baseado em Coughlan e Coughlan, 2002).

- Qual seu cargo na empresa?

- Você faz parte do novo arranjo societário da empresa?

- Os projetos atuais estão correlacionados com a estratégia vigente da empresa?

- Os projetos estão sendo entregues de acordo com os prazos, custos e objetivos esperados e pactuados?

- Quais os principais problemas que impactam a entrega de projetos na empresa atualmente?

- Você acredita que estes problemas o impedirão de atingir os novos objetivos estratégicos propostos?

- Quais resistências devem ser superadas?

Roteiro de perguntas para verificação dos benefícios e fatores limitantes

- Qual seu cargo na empresa?

- Quais foram os benefícios da implantação de um Escritório de Gerenciamento de Projetos na empresa?

- No seu entendimento, quais foram os fatores limitantes desta implantação?

- E os fatores de sucesso?

- Atualmente, o escritório de projetos atua da forma como você imaginou que ele atuaria?

- Quais os principais custos envolvidos na implantação? 


\section{APÊNDICE 03: ESTRUTURA PARA ANÁLISE DE CONTÉUDO}

Estrutura para análise de conteúdo das entrevistas de diagnóstico e situação-problema

\begin{tabular}{|l|l|l|}
\hline CATEGORIA & SUBCATEGORIA & CONTEÚDO \\
\hline Gerenciamento de projetos & Má execução de projetos & Motivos para a má execução \\
\hline Gerenciamento de projetos & Solução para má execução & $\begin{array}{l}\text { Formatos de solução e } \\
\text { impactos na organização }\end{array}$ \\
\hline
\end{tabular}

Estrutura para análise de conteúdo das entrevistas de verificação dos benefícios e fatores limitantes

\begin{tabular}{|l|l|l|}
\hline CATEGORIA & SUBCATEGORIA & CONTEÚDO \\
\hline EGP & Benefícios & Lista de benefícios \\
\hline EGP & Fatores Limitantes & Lista de fatores limitantes \\
\hline EGP & Fatores de Sucesso & Lista de fatores sucesso \\
\hline EGP & Custos & Lista de custos envolvidos \\
\hline
\end{tabular}




\section{APÊNDICE 04: EXEMPLO DE PLANILHA EM EXCEL QUE ESTRUTUROU OS PROJETOS ESTRATÉGICOS DA ORGANIZAÇÃO}

Adicionalmente à ficha de projeto, a planilha continha: principais atividades dos grandes marcos, ponderação da relevância da atividade para a entrega do projeto, entregáveis, relação de interdependência entre as atividades, responsáveis e participantes de cada atividade, início previsto, término previsto, início real, término real e farol (diferença entre o início e o término previsto e realizado). 


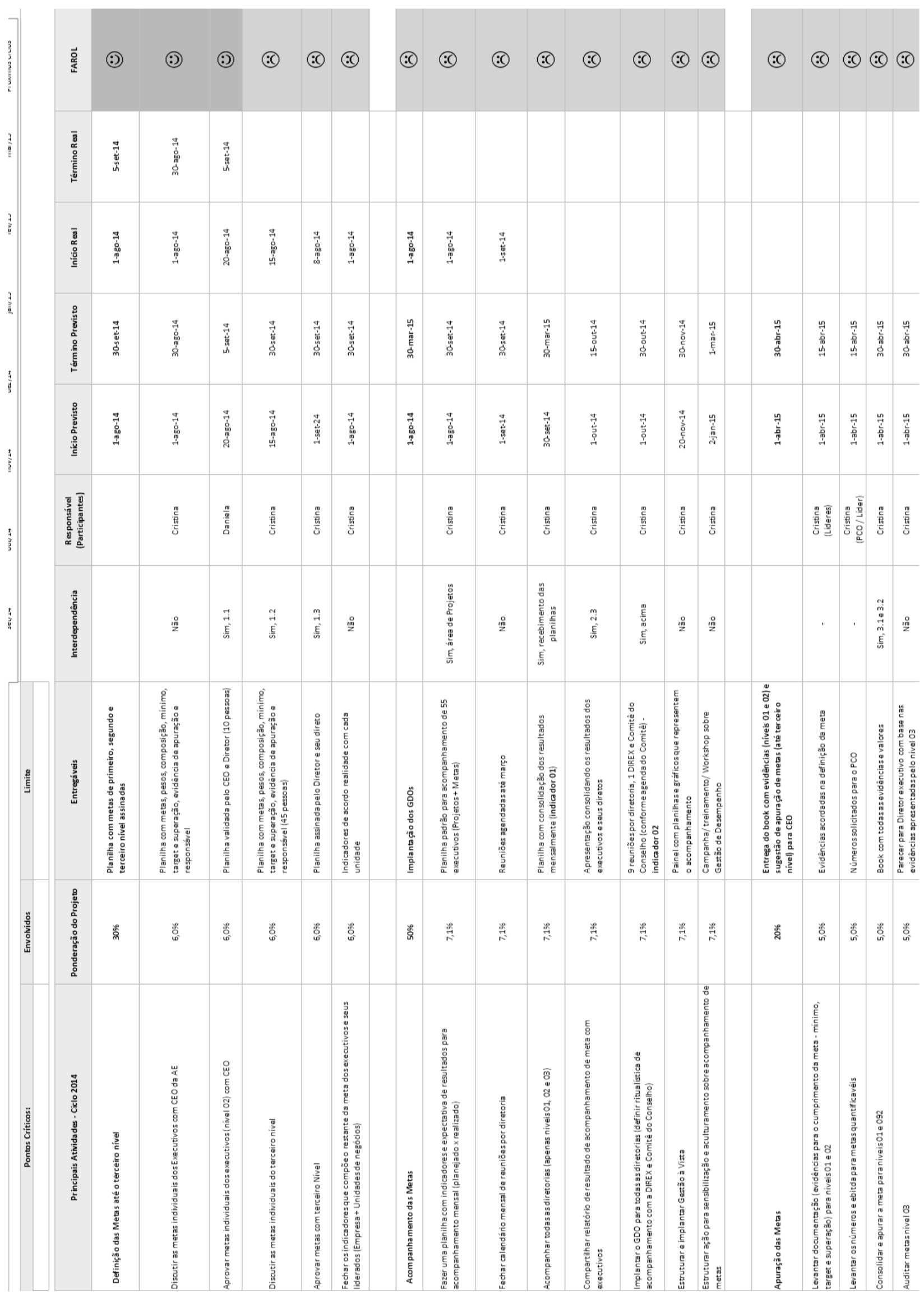

